Martyna Kołodziejczak

przy współpracy Ireny Jajte-Lewkowicz

https://doi.org/10.18778/8220-636-4.04

\title{
ŁÓDZKIE SPOTKANIA BALETOWE - PRESTIŻ I EDUKACJA
}

Łódź bez wątpienia jest miastem, którego codziennością są festiwale. Co kilka tygodni, a może nawet dni, organizowane są większe bądź mniejsze imprezy poświęcone różnym rodzajom sztuk: począwszy od filmowej, teatralnej, muzycznej, nowych mediów, plastyki, designu, poprzez sztukę mody, ubioru, tatuażu, a na sztuce kulinarnej kończąc. Wśród tej mnogości propozycji warto przypomnieć, że jednym z najstarszych łódzkich festiwali ${ }^{1}$ - i wciąż najbardziej prestiżowym lokalnym wydarzeniem artystycznym - są Łódzkie Spotkania Baletowe. Przegląd, zainicjowany w roku 1968, jest jednocześnie najstarszym i największym festiwalem tańca w Polsce, jednym z ważniejszych w Europie, należy też do kilkunastu najstarszych festiwali teatralnych w Polsce ${ }^{2}$.

Łódzkie Spotkania Baletowe organizowane są jako festiwal tematyczny, międzynarodowy, przygotowany przez jedną placówkę - Teatr Wielki w Łodzi. Festiwal jest instytucją publiczną, finansowaną przede wszystkim przez Urząd Marszałkowski Województwa Łódzkiego. Mecenasami są także: Urząd Miasta Łodzi, Ministerstwo Kultury i Dziedzictwa Narodowego, a od wielu lat także sponsorzy prywatni. ŁSB nie mają charakteru konkursowego, stanowią przegląd widowisk, odbywają się $\mathrm{w}$ formie biennale, zawsze na przełomie maja i czerwca - $\mathrm{z}$ wyjątkiem XXII edycji w 2013 roku, która przeprowadzona została na przełomie października i listopada (z powodu prac modernizacyjnych w Teatrze Wielkim).

Festiwal powstał rok po otwarciu budynku teatralnego znajdującego się przy Placu Dąbrowskiego, w centrum miasta. Ów ogromny gmach wpisuje się mocno w dzieje Biennale, jednocześnie poświadczając ewolucję urbanistycznego i społecznego charakteru miasta. Teatr pewnie nie zyskałby tak monumentalnej formy

1 Cztery lata wcześniej, w 1964 roku, powstały Łódzkie Spotkania Teatralne.

2 Dorota Buchwald, Wspótczesne festiwale w Polsce. Typologia i geografia, [w: ] Mię$d z y$ świętem a przesytem. Festiwale teatralne i ich miejsce we współczesnym życiu kulturalnym Polski, red. Dariusz Kosiński, Teatr Lalek „Pleciuga”, Szczecin 2016, s. 22. 
(był wówczas jednym z największych budynków operowych w Europie i nadal plasuje się na czwartym miejscu), gdyby nie ambicje lokalnych władz, by w proletariackim mieście prezentować efektowne inscenizacje i wielkie zespoły - ku satysfakcji i wytchnieniu ludzi pracy. A także, by można tu organizować zjazdy, kongresy i imprezy masowe. Teatr miał stanowić wyrazisty projekt polityczny: zatem dbając o właściwy ideologicznie wizerunek Wielkiego, który spełniałby wyobrażenia o demokratycznym charakterze polskiej kultury - pozbawiono widownię tradycyjnych lóż...

Koncepcja teatru była dziełem Józefa i Witolda Korskich ${ }^{3}$ oraz Romana Szymborskiego. Projektując teatr, architekci pozostali wierni stylowi klasycyzującemu i modernistycznemu, co uchroniło gmach przed zbyt natrętnym piętnem maniery socrealistycznej. Jak się przypuszcza, nawiązali też do projektu Teatru Miejskiego, przygotowanego dla Łodzi (i niestety niezrealizowanego) w roku 1924 przez słynnego architekta - Czesława Przybylskiego ${ }^{4}$. Budynek, stawiany już od roku 1949, pomyślany był początkowo jako siedziba Teatru Narodowego, czyli teatru dramatycznego, który miał tu stworzyć Leon Schiller. Choć w pierwszym okresie budowa prowadzona była w systemie trójzmianowym, to z powodu wielu modyfikacji inwestycyjnych oraz kłopotów organizacyjnych gmach w pełni oddano do użytku dopiero po osiemnastu latach, 19 stycznia 1967 roku, nieco wcześniej udostępniając jedynie sale prób artystom. Z pierwotnego zamysłu, by teatr stał się narodową scenę dramatyczną, zrezygnowano (także w wyniku sugestii Kazimierza Dejmka) i postanowiono stworzyć tu teatr operowy. W budynku zaplanowana została widownia:

[... ] na 1300 miejsc oraz nowoczesna scena, największa w tym czasie w kraju i jedna z większych w Europie, o wymiarach 27 metrów szerokości i 20 metrów głębokości (prawie 40 metrów głębokości wraz z zasceniem), wyposażona w liczne zapadnie sceniczne i osobowe oraz scenę obrotową o średnicy 16 metrów $^{5}$.

3 Józef (Kaban) Korski w latach 20. XX wieku był w Łodzi architektem powiatowym i to według jego projektów powstały m.in. tak znane lódzkie obiekty jak położony obok Teatru, stanowiący wschodnią pierzeję Placu Dąbrowskiego Sąd Okręgowy, Pałac Biskupi przy ul. Skorupki czy budynki Izby Skarbowej oraz centrali telefonicznej PAST przy al. Kościuszki. Także jego syn Witold był wybitnym architektem.

4 Twórcy m.in. projektów: Teatru Polskiego w Warszawie i Teatru Miejskiego w Kaliszu. Zob. Witold Korski, O projekcie Teatru Wielkiego w Łodzi, za: wortal poświęcony architekturze budynków teatralnych, https://www.theatre-architecture.eu/pl/ $\mathrm{db} /$ ?theatreId $=269$ (dostęp: 15.12.2016).

5 Piotr Gryglewski, Robert Wróbel, Agnieszka Ucińska, Łódzkie budynki 19451970, Księży Młyn Dom Wydawniczy, Łódź 2012, s. 99. 
Tak imponująca scena mogła sprostać najbardziej wyrafinowanym wymaganiom i wizjom artystycznym. Na inaugurację wystawiono nie jedną, lecz - dzień po dniu - aż cztery premiery: Halkę Stanisława Moniuszki (jej IV akt transmitowała raczkująca Telewizja Polska), Kniazia Igora Aleksandra Borodina, Straszny dwór Moniuszki i Carmen Georgesa Bizeta. Kolejne realizacje nie ustępowały rozmachem pierwszym. Scena służyła zespołowi TW, bez istotnych zmian, przez 45 lat. Pewnych remontów budynku dokonano na początku XXI wieku, ale kompleksową modernizację Wielki przeszedł dopiero w roku 2012, dzięki pozyskaniu funduszy unijnych.

W wymiarze artystycznym Teatr podjął misję i działalność Opery Łódzkiej, powołanej w Łodzi w roku 1954 z inicjatywy Stowarzyszenia Przyjaciół Opery Łódzkiej, dzięki staraniom artystów i pedagogów łódzkich uczelni muzycznych: Władysława Raczkowskiego, Tomasza Kiesewettera i Mieczysława Drobnera ${ }^{6}$. Stowarzyszenie - kierujące Operą do roku 1961, kiedy to ją upaństwowiono - nawiązywało do miejscowych tradycji teatralnych i prób utworzenia w mieści stałej sceny operowej, co się wcześniej nie udało 7 . Nim Opera Łódzka doczekała się nowego gmachu i nazwy - nawiązującej do miana przedwojennego Teatru

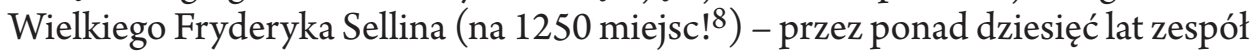
dawał swoje premiery na deskach Teatru Nowego oraz Teatru im. Stefana Jaracza. Na czele Opery stanęła Sabina Nowicka - „Legenda teatru łódzkiego”9, współpracowniczka m.in. Schillera i Dejmka, współzałożycielka i dyrektorka łódzkich teatrów. Nowickiej udało się sprowadzić do Łodzi samego Feliksa Parnella, wybitnego polskiego tancerza, choreografa i pedagoga, który w roku 1957 utworzył przy Operze trzydziestoosobowy zespół baletowy. „Być może nigdy nie trafiłby do Łodzi, gdyby nie konflikt w Operze Poznańskiej, gdzie od 1954 roku był kierownikiem baletu. [... Tę sytuację sprytnie wykorzystała Sabina Nowicka [... i zaproponowała Parnellowi przejście do Łodzi”10. Z Łodzią Parnell związał

6 Zob.: Sto lat statej sceny polskiej w Eodzi 1888-1988, red. Anna Kuligowska, Towarzystwo Przyjaciół Łodzi, Łódź 1993, s. 332.

7 Ibidem, s. 292.

8 Teatr Wielki działał w Łodzi od roku 1901 do 1920, kiedy to uległ spaleniu, zob.: Sto lat stałej sceny..., s. 282.

9 Określenie Anny Kuligowskiej-Korzeniewskiej, zob.: Anna Kuligowska-Korzeniewska, Sabina Nowicka. Legenda teatru łódzkiego, „Zeszyty Literackie” 2006, nr 3(95).

10 Joanna Leszczyńska, Nie potrafit oddzielić życia od baletu, „Polska Dziennik Łódzki” 2010, nr 111, cyt. za: Internetowa Encyklopedia Teatru Polskiego, http://www. encyklopediateatru.pl/artykuly/94103/nie-potrafil-oddzielic-zycia-od-baletu (dostęp: 15.10.2016). 
się już na stałe, aż do swojej śmierci w roku 1980. Artysta uzyskał tu swobodę w kształtowaniu zespołu baletowego i decydowaniu o jego repertuarze; na tutejszych scenach realizował własne nieprzeciętne choreografie i stworzył łódzkie szkolnictwo baletowe ${ }^{11}$.

Dzieje Teatru Wielkiego to oczywiście osobna karta w historii łódzkiej i polskiej kultury, w tym miejscu trzeba poprzestać na przypomnieniu, że na scenie przedstawiono do roku 2016: „[...] ponad 300 premier, wśród których były klasyczne dzieła operowe i baletowe, musicale i operetki, a także kompozycje wybitnych współczesnych twórców polskich"12. Bywanie na przedstawieniach w Wielkim przez lata decydowało o towarzyskim statusie (nie tylko) łódzkich melomanów. Ranga i poziom artystyczny prezentowanych tu wydarzeń skłoniły nawet Jerzego Waldorffa do zainicjowania stołecznych „pociągów muzycznych”, zwożących do Łodzi warszawskich miłośników opery i baletu ${ }^{13}$.

Jednym z najważniejszych elementów kulturalnej ekspansji Teatru Wielkiego stało się zorganizowanie w roku 1968 Łódzkich Spotkań Baletowych. Stanisław Dyzbardis, wieloletni dyrektor $Ł S B$ wspominał:

[...] zastanawialiśmy się w jaki sposób można wypromować tę ogromną instytucję. Nie tylko w Polsce. Inauguracja Wielkiego obywała się w atmosferze dyskusji czy jest on Łodzi potrzebny, bo przecież opera to gatunek sztuki - jak mówiono - który już umiera. Przeciwnicy gwaltownie protestowali przeciw oddaniu gmachu Operze Łódzkiej. Tak zrodził się pomysł tego festiwalu ${ }^{14}$.

[...] To miała być jednorazowa impreza. Nie mówiłem widzom: „Witam na pierwszym festiwalu", bo nie przypuszczałem, że w ogóle będzie drugi ${ }^{15}$.

11 Aleksandra Stanisławska, Feliks Parnell - narodziny baletu tódzkiego, [w: ] Łódzka scena operowa, red. Krystyna Juszyńska, Akademia Muzyczna im. Grażyny i Kiejstuta Bacewiczów, Łódź 2005, s. 245-254; Sto lat stałej sceny... , s. 332.

12 Cyt. za: Konferencja prasowa, sezon 2015/2016, Teatr Wielki w Łodzi, http:// www.operalodz.com/files/docs/konferencja_prasowa_2015x.pdf. Informacje na temat Teatru Wielkiego w Łodzi: Teatr Wielki w Łodzi, red. Stanisław Dyzbardis, Teatr Wielki w Łodzi, Łódź 1966; Łódzka scena operowa ...; Tomasz Graczyk, Teatr Wielki w Łodzi 1967-2007, Teatr Wielki w Łodzi, Łódź 2007.

13 Zob.: Stanisław Dyzbardis, Monika Wasilewska, Rozmowa ze Stanisławem Dyzbardisem, wicedyrektorem Teatru Wielkiego, „Gazeta Wyborcza - Łódź” (18 stycznia 2002), http://lodz.wyborcza.pl/lodz/1,35135,652020.html (dostęp: 15.10.2016).

14 Stanisław Dyzbardis, Łódź tańczy..., „Kalejdoskop” 2005, nr 5, s. 2.

15 Stanisław Dyzbardis, Monika Wasilewska, Wierzę w sitę baletu, „Gazeta Wyborcza - Łódź” (12 maja 2007), http://www.e-teatr.pl/pl/artykuly/38948.html?josso_assertion_id=76E3AAC0934BBF4A (dostęp: 15.10.2016). 
Ale nawet wówczas powstających w Teatrze Spotkań nie dałoby się sprowadzić do roli narzędzia propagandowego politycznych decydentów. Przeciwnie, to tutaj od początku istnienia $€ S B$ redefiniowano nowe prądy artystyczne, kwestionowano kanony - sztuki i myślenia o sztuce. Jak można sądzić, kulturowym impulsem do powstania pierwszego w Polsce festiwalu tańca była ważna dyskusja prowadzona $\mathrm{w}$ środowisku artystów w drugiej połowie lat 60 . XX wieku, poświęcona pilnej potrzebie stworzenia przestrzeni „konfrontacji osiągnięć i niedostatków polskiej choreografii"16. Debata przybrała na sile w roku 1966, w trakcie III „Milenijnego” Kongresu Kultury Polskiej, w którym brała udział m.in. Janina Jarzynówna-Sobczak, wybitna choreografka, współtwórczyni polskiego baletu współczesnego. W pokongresowej atmosferze krystalizowała się idea stworzenia ogólnopolskiego festiwalu tańca ${ }^{17}$.

Inicjatorami ŁSB była ówczesna dyrekcja Teatru Wielkiego w Łodzi, którą stanowili: Stanisław Piotrowski (dyrektor naczelny TW), Zygmunt Latoszewski (dyrektor artystyczny, dyrygent, reżyser, pedagog), Witold Borkowski (kierownik baletu, tancerz i znakomity choreograf) oraz Stanisław Dyzbardis (kierownik literacki). O międzynarodowym charakterze rodzącego się wydarzenia zdecydowało zapewne pragnienie wypromowania Teatru Wielkiego. W czasie pierwszego festiwalu to „umiędzynarodowienie” było nadzwyczaj skromne; zagranicę reprezentowała jedynie Państwowa Opera w Lipsku (NRD).

„Ideą festiwalu - jak od początku deklarowali organizatorzy - jest upowszechnianie sztuki baletowej i aktualnych osiągnięć choreograficznych, zarówno na polu tańca klasycznego, jak i różnorodnych nurtów tańca współczesnego", a także stworzenie z łódzkiej sceny „[...] forum konfrontacji tego, co w sztuce baletu i teatru tańca najwartościowsze, aktualne i godne odnotowania"18. Obserwacja już blisko pięćdziesięcioletniej historii Spotkań ${ }^{19}$ potwierdza wiarygodność zobowiązania twórców festiwalu.

Ponieważ nie sposób wyczerpująco opisać w tym artykule całej historii ŁSB, zostaną tu przedstawione jedynie wybrane wydarzenia, które wydają się dobrze oddawać artystyczny profil festiwalu i wyznaczają jego podstawowe tendencje rozwojowe.

„Warto zauważyć - pisał Janusz Janyst - że już pierwsza edycja była stylistycznie spolaryzowana. Ukazywanie przeciwstawnych sobie często nurtów obecnych

16 Irena Turska, Almanach baletu polskiego, 1945-1974, Polskie Wydawnictwo Muzyczne, Kraków 1983, s. 192.

17 Ibidem.

18 Cyt. za: strona internetowa Teatru Wielkiego w Łodzi, zakładka: O ŁSB, http:/ / www.operalodz.com/lsb/O_LSB,53 (dostęp: 20.11.2016).

19 [Artykuł powstał na przełomie lat: 2016/2017 - przyp. red.] 
w praktyce baletowej II połowy XX wieku stało się programowym założeniem przeglądu, konsekwentnie wcielanym w życie w kolejnych latach" 20 . W czasie I Festiwalu charakter owej polaryzacji wyraziście reprezentowało zestawienie premierowego widowiska Państwowej Operetki Warszawskiej, czyli Różowych baletów (Jerzego Smoczyńskiego/ Jerzego Kaplińskiego) z twórczością samej Janiny Jarzynówny-Sobczak. Artystka pokazała w Łodzi trzy utwory w swojej choreografii, inscenizacji i scenografii, w tym dwa będące przykładami jej nowych (z 1967 r.) i najznakomitszych prac: jednoaktowy balet Niobe Juliusza Łuciuka oraz Tytanię i osła Zbigniewa Turskiego. Obydwa dzieła stanowiły prawdziwe wyzwanie dla tradycyjnych upodobań estetycznych, przemawiały językiem nowoczesnego tańca, dopiero rodzącym się na polskiej scenie. Jarzynówna-Sobczak jeszcze dwukrotnie gościła na ŁSB - w roku 1970 na II Spotkaniach oraz w roku 1974, na IV ŁSB. W 1974 roku wykład artystki pt. Teatr i taniec, wzajemne zwiazki między aktorstwem, śpiewem i tańcem, między reżyserią i choreografią otworzył międzynarodową konferencję Teatr i taniec, towarzyszącą IV Biennale ${ }^{21}$, co manifestowało twórcze przywództwo Jarzynówny-Sobczak także w obszarze ówczesnych prób konceptualizacji sztuki tańca w Polsce.

Przegląd wydarzeń I Festiwalu pośrednio ujawnia jeszcze jedną charakterystyczną cechę łódzkich Spotkań - możliwość obejrzenia na scenie Wielkiego najlepszych tancerzy. W Niobe i w Tytanii... tańczyła swoje sławne role Alicja Boniuszko, primabalerina gdańskiej sceny, jedna z najwybitniejszych polskich tancerek. Zaś partię Onej w Różowych baletach kreowała była primabalerina Oper: Poznańskiej, Śląskiej i Warszawskiej, a ówcześnie Operetki Warszawskiej, świetna także aktorsko - Barbara Bittnerówna. Wyraz doświadczeniu obcowania z tak zachwycającą różnorodnością tańca dał, recenzujący przedstawienia, historyk polskiego teatru i współtwórca łódzkiej teatrologii - Stanisław Kaszyński:

W tej partyturze błyszczy A. Boniuszko, lecz solo - kryształ, w którym załamują się wszystkie tworzywa baletowej syntezy, ma twarz skupioną, zmartwiałą, wystygłą; tak grała Niobe. [...] Jej przeciwieństwem była na Spotkaniach Barbara Bittnerówna. Spazm wewnętrzny i tragiczną maskę Boniuszko roztopiła w uśmiechu, pogodzie i rozkołysaniu wigorem. Cóż za płynność i krągłość tańca!22

20 Janusz Janyst, Sfera Terpsychory, „Tygiel Kultury” 2009, nr 7-9, http://www. amuz.lodz.pl/dmdocuments/janyst_artykul.pdf (dostęp: 12.10.2016).

21 Irena Turska, Almanach ..., s. 197.

22 Stanisław Kaszyński, Święto baletu. Uwagi i refleksje, „Odgłosy. Tygodnik Społeczno-Kulturalny” 1968, nr 24, s. 7, http://bc.wimbp.lodz.pl/Content/66205/Odglosy1968nr24.pdf (dostęp: 10.10.2016). 
Dodajmy, że w czasie tej samej edycji Festiwalu występowała także inna gwiazda tańca - Krystyna Mazurówna.

Podsumowując pierwsze Biennale, Profesor Kaszyński pisał: „Troską i ambicją organizatorów będzie podniesienie rangi Spotkań przez przywoływanie do Łodzi najlepszych i różnorodnych pod względem artystycznym ensambli"23 - a wśród tych najbardziej pożądanych na pierwszym miejscu wymieniał zespół Maurice’a Béjarta, którego twórczość polska publiczność mogła podziwiać wcześniej w Warszawie ${ }^{24}$.

Już w czasie II Spotkań, w roku 1970, widzowie zobaczyli na deskach Wielkiego słynny Ballet du XX-e siècle (Balet XX Wieku), stworzony przez Béjarta w roku 1960 w Brukseli. Z pewnością było to dla młodego łódzkiego festiwalu wydarzenie fundacyjne, a jego zaistnienie miało charakter „szoku estetycznego i kulturowego"25. Zespół przywiózł do Łodzi swoje bardzo znaczące dzieła, w których choreograf, w charakterystyczny dla siebie sposób, dążył do ukazania fizycznej intensywności tańca ${ }^{26}$, eksponując jednak zarówno ciało tańczącego człowieka, jak i jego osobowość. A warto przypomnieć, że Béjart współpracował w swojej karierze z takimi tancerzami i tancerkami jak Rudolf Nuriejew, Maja Plisiecka, Michaił Barysznikow, Carla Fracci czy Sylvie Guillem. Niezwykle śmiało - jak na ówczesne lata - łączył także Béjart taniec z pieśnią, recytacją, grą dramatyczną, projekcjami filmowymi. Na łódzkiej scenie pojawił się artysta, który był jednym $\mathrm{z}$ najważniejszych innowatorów tańca i współczesnej choreografii, ich reformatorem i filozofem. Podczas występów Ballet du XX-e siècle festiwalowa publiczność mogła doświadczyć prawdziwego fenomenu - objawienia istoty współczesnego tańca w najlepszym wykonaniu.

Béjart zaprezentował w Łodzi swoje trzy słynne obrazy baletowe. Rozpoczynał wieczór Actus Tragicus do dwóch Kantat Johanna Sebastiana Bacha - 106 i 51

23 Ibidem.

24 Pierwszy raz Béjart przyjechał do Warszawy w roku 1966, w roku 1970 pokazał tam, przed łódzkimi występami, Romea i Julię Hectora Berlioza. W przedstawieniu tańczył m.in. Woytek Lowski/Voytek Lovski, czyli Wojciech Wiesiołłowski, wybitny polski tancerz współpracujący z Baletem XX Wieku. Artysta brał udział również w łódzkich spektaklach: tańczył jako solista w Actus Tragicus. W zespołach Béjarta występowali także inni polscy tancerze: Gerard Wilk, Andrzej Ziemski, Piotr Nardelli, Dariusz Blajer, Waldemar Wołk-Karaczewski, Katarzyna Gdaniec.

25 Jak nazwał to wydarzenie Stanisław Dyzbardis, za: Joanna Brych, Niezwykła kariera Gerarda Wilka, „Polityka” (22 marca 2016), https://www.polityka.pl/tygodnikpolityka/ludzieistyle/1654964,1,niezwykla-kariera-gerarda-wilka.read (dostęp: 10.10.2016).

26 Por.: Wojciech Klimczyk, Wizjonerzy ciała. Panorama wspótczesnego teatru tańca, Korporacja HA!ART, Kraków 2010, s. 46. 
(prapremiera: Bruksela 24XII 1969) - dzieło, które podejmowało temat śmierci, czyli jeden z najważniejszych motywów twórczości artysty. I czyniło to zgodnie z jego zamysłem: „Taniec śledzi tutaj intencje muzykalne i religijne partytury, pragnąc być tylko wizualnym kontrapunktem śpiewu" 27 . Współbrzmi to z opinią na temat sztuki Béjarta Tacjanny Wysockiej: „Muzykę nie tylko się słyszy, muzykę się widzi"28. Temat śmierci pojawił się też w: Serait-ce la mort?, czyli balecie w jednym akcie do pierwszej spośród Czterech ostatnich pieśni Richarda Straussa, do tekstów Hermanna Hessego i Josepha von Eichendorffa (prapremiera: Marsylia 5 IV 1970), wielokrotnie grywanemu w tej choreografii do dziś. Występ zamykało jedno z najlepszych dzieł w twórczości Béjarta: Bhakti (prapremiera tych scen baletowych opartych na tematach i muzyce hinduskiej odbyła się w Pałacu Papieskim w Awinionie 26 VII 1968). Bhakti, interpretując metafizyczny wymiar miłości, przywoływało pary bóstw $\mathrm{z}$ hinduistycznego panteonu, których role kreowali legendarni soliści Ballet du XX-e siècle: Rama (Paolo Bortoluzzi, wówczas niekwestionowana gwiazda zespołu, później m.in. partner sceniczny Nuriejewa) i Sita (Orié Ohara); Kryszna (młody Jorge Donne, uosabiający styl Béjartowskiego tańca, inspirator wielu jego choreograficznych arcydziel) i Radża (wspaniała Tania Bari); Śiwa (Germinal Casado, nie tylko wybitny tancerz, ale także scenograf; to on stworzył kostiumy do Bhakti) i Śakti (Maïna Gielgud, córka znakomitego aktora, także partnerka sceniczna Nuriejewa, a dziś znana choreografka). „To co mnie interesuje w myśli indyjskiej - pisał Béjart w programie - to nie strona folklorystyczna, lecz myśl filozoficzna, która [... ] stanowi większą wartość niż wszystkie systemy zachodnie" 29 . Także tej cechy współczesnego tańca - jego głębokiego nasycenia refleksją - uczyła się łódzka publiczność od francuskiego mistrza. Fakt przyjęcia zaproszenia przez Béjarta na niemal debiutujący festiwal, uświadamia artystyczny rozmach, z jakim Biennale powstawało.

Maurice Béjart ponownie przyjechał z Ballet du XX-e siècle do Łodzi na VIII Spotkania, w roku 1985. „Wtedy to właśnie - jak wspominał Janusz Janyst - Ravelowskie Boléro z tańczącym główną partię na wielkim stole Jorge Donnem okazało się przeżyciem przerastającym intensywnością wszystko, co na festiwalu można było dotąd obejrzeć" 30 , i co do dziś pozostało w pamięci widzów jednym z najważniejszych wydarzeń w dziejach ŁSB. Niezwykły utwór, skomponowany

27 Maurice Béjart, Actus Tragicus, Program teatralny: Balet XX wieku Belgijskiej Opery Narodowej, II Łódzkie Spotkania Baletowe 1970, Teatr Wielki w Łodzi, opr. Stanisław Dyzbardis, brak nazwiska tłumacza, s. 5.

28 Tacjanna Wysocka, Dzieje baletu, Państwowy Instytut Wydawniczy, Warszawa 1970, s. 2017.

29 Maurice Béjart, Bhakti, Program teatralny: Balet XX wieku... , s. 7.

30 Janusz Janyst, Sfera Terpsychory... 
przez Ravela w 1911 roku na zamówienie Idy Rubinstein - która napisała libretto i tańczyła solową partię w choreografii Bronisławy Niżyńskiej - Béjart przepisał na ekspresję męskiego ciała i powierzył Donnowi ${ }^{31}$. Jak pisała Elżbieta Pastecka: „Zrodzone z geniuszu duetu twórców: Béjarta i Donna choreograficzne arcydzieło uświadamiało oglądającym rzeczywistą, rytualną funkcję tańca, jego magiczne oddziaływanie zarówno na widza jak i wykonawcę" 32 , co stało się także udziałem festiwalowej publiczności. Cztery lata po śmierci Béjarta, na XXI Spotkania w 2011 roku, które zostały poświęcone wybitnym choreografom drugiej połowy XX wieku, przyjechał Béjart Ballet Lausanne - zespół założony przez artystę po likwidacji jego pierwszego teatru (1987) i przeniesieniu ansamblu do Lozanny w Szwajcarii. Grupa pokazała wówczas m.in. balet Dionysos (Suite) z 1985 roku, do muzyki Richarda Wagnera i Manosa Hadjidakisa, jedno z najsłynniejszych dzieł choreograficznych swojego mistrza (kostiumy zaprojektował Gianni Versace). Przedstawiono także Le Chant du compagnon errant [Pieśń wędrownego czeladnika], do muzyki Gustava Mahlera, utwór interpretowany jako opowieść o samym Béjarcie, w którego twórczości (i w życiu) kategoria podróży stanowiła jedną z podstawowych metafor ${ }^{33}$. Béjartowskie choreografie pojawiały się na Biennale także w wykonaniu innych zespołów, jak np. Państwowej Opery w Budapeszcie (Czyżby to byta śmierć?, Ognisty ptak na V ŁSB w 1976 r.).

Twórczość Béjarta zajęła tu tak dużo miejsca, ponieważ to właśnie dzięki wizycie Ballet du XX-e siècle Spotkania zyskały swój nowoczesny i do dziś rozpoznawalny charakter, a wraz z nim międzynarodowe uznanie i prestiż, które pozwolity w kolejnych latach sprowadzać do Łodzi najlepsze grupy taneczne. W czasach, gdy w Polsce balet w powszechnym odbiorze kojarzony był z klasyką, na ŁSB można było zobaczyć nie tylko nowe techniki tańca, ale także zupełnie nowy typ widowiska baletowego. Taniec na łódzkim festiwalu, na wzór tańca w zespołach

31 Béjart kilkakrotnie opracowywał choreograficznie Boléro. Pierwsza wersja utworu pochodziła z roku 1961 i przeznaczona była dla kobiety - serbskiej tancerki Dušanki/Duški Sifnios. W 1979 roku jako pierwszy mężczyzna zatańczył choreografię Béjarta właśnie Jorge Donn, por. np. Antoine Livio, Béjart, La Cité, Lausanne, Paris, 1970.

32 Elżbieta Pastecka, Jorge Donn, portal: www.maestro.net.pl http://www.maestro. net.pl/document/memory/Donn.pdf (dostęp: 10.09.2016).

33 Zob.: Program teatralny: XXI ŁSB, „Wybitni choreografowie XX wieku”, Teatr Wielki w Łodzi, red. Iwona Marchewka, Maria Rżanek, Łódź 2011, s. 28-22; Dariusz Pawłowski, Łódzkie Spotkania Baletowe. Zachwycający Béjart Ballet Lausanne, „Dziennik Łódzki” (14 maja 2011), http:/ /lodz.naszemiasto.pl/artykul/lodzkie-spotkania-baletowe-zachwycajacy-bejart-ballet,906297,artgal,t,id,tm.html (dostęp: 20.08.2016); Antoine Livio, Béjart... 
Béjarta, coraz śmielej: „Sentymentalizmowi i ulotności tańca klasycznego przeciwstawił siłę, moc i energię tkwiącą w ludzkim ciele"34.

Na II ŁSB publiczność podziwiała także dzieła Conrada Drzewieckiego - polskiego pioniera i reformatora tańca współczesnego, świetnego tancerza, reżysera, scenografa i pedagoga ${ }^{35}$. Do Łodzi przyjechał Drzewiecki już w roku 1970, wówczas z Baletem Opery Poznańskiej, jako jego kierownik i choreograf. To właśnie na poznańskiej scenie stworzył, jak pisze Jagoda Ignaczak, swoje „[...] oryginalne kompozycje choreograficzne, w których dominującym staje się język oparty na syntezie neoklasyki, tańca współczesnego i stylizacji tańców narodowych"36. Opera Poznańska przedstawiła na II Spotkaniach m.in. znakomite spektakle Drzewieckiego powstałe w roku 1967: Ognistego ptaka Igora Strawińskiego i Adagio na smyczki i organy Tomasa Albinoniego. Od tej pory nieomal każde kolejne Biennale prezentowało prekursorskie choreografie artysty i stworzone przez niego nowe formy widowiska teatralnego - (polskiego) teatru tańca. Na III ŁSB (1972) Drzewiecki pokazał cykl choreografii do muzyki Béli Bartóka: Sonatę na dwa fortepiany i perkusję (1972), Divertimento (1970) i jedno z najcenniejszych dzieł polskiego repertuaru choreograficznego - utrzymaną w poetyce teatru absurdu interpretację Cudownego Mandaryna (1970). Od IV edycji festiwalu Drzewiecki przyjeżdżał ze stworzonym przez siebie w roku 1973 autorskim zespołem rozwijającym jego idee tańca: Polskim Teatrem Tańca - Baletem Poznańskim, wówczas - i przez wiele kolejnych lat - pionierską i najlepszą grupą tańca współczesnego w Polsce, która na ŁSB śmiało stawała do konfrontacji $\mathrm{z}$ osławionymi zespołami zagranicznymi. Balet sukcesywnie przedstawiał w Łodzi dzieła swojego mistrza. I tak: w czasie V Spotkań (1976) pokazał świetne Odwieczne pieśni Mieczysława Karłowicza (1975), stanowiące także przykład współpracy Drzewieckiego ze znakomitym plastykiem - Krzysztofem Pankiewiczem. Na VI Spotkania PTT - BP przywiózł program składający się z Dramatic story Kazimerza Serockiego, Kwintetu C-dur Franza Schuberta oraz - uznawanego za jedno z najlepszych dzieł Drzewieckiego - Krzesanego Wojciecha Kilara. Już od chwili prapremiery w 1977 roku Krzesany niezmiennie zachwycal polskich i za-

34 Jacek Marczyński, Monika Małkowska, Maurice Bejart wierzyt, że taniec jest pięknem i radością, „Rzeczpospolita” (22 listopada 2012), http://www.rp.pl/artykul/71078-Maurice-Bejart-wierzyl--ze-taniec-jest-pieknem-i-radoscia.html (dostęp: 20.11.2016).

35 Zob.: Stefan Drajewski, Conrad Drzewiecki. Reformator polskiego baletu, Dom Wydawniczy Rebis, Poznań 2014.

36 Jagoda Ignaczak, Conrad Drzewiecki (1926-2007), tekst towarzyszący audio-video performance Polskiego Teatru Tańca: Conrad Drzewiecki - in memoriam. Artyści wczoraj i dziś, premiera 16 X 2012, wortal: http://kultura.poznan.pl/mim/kultura/ news/historia,c,8/conrad-drzewiecki-1926-2007,55556.html (dostęp: 15.08.2016). 
granicznych odbiorców. Międzynarodowa krytyka podkreślała jego fascynującą dynamikę i energię, nowatorski sposób wykorzystania w choreografii folkloru i taneczną ekspresję wolności, zestawiając utwór ze Świętem wiosny Strawińskiego ${ }^{37}$. Łódzkie wykonanie stanowiło także, jak pisano: „[... ] popis tańca uderzającego czystością kompozycji i zachwycającego perfekcją wykonania"38. Kolejna wizyta poznańskiego zespołu przypadła na rok 1983 (VII ŁSB), kiedy to obchodzono dwusetną rocznicę powstania polskiego baletu, czyli inauguracji w Grodnie działalności zespołu hrabiego Antoniego Tyzenhauza. Trudno było jednak radośnie świętować jubileusz wobec panującej w kraju sytuacji społeczno-politycznej i ciągle obowiązującego stanu wojennego. PTT przywiózł wówczas wieloczęściowy spektakl zatytułowany Spotkanie z Conradem Drzewieckim. Przedstawienie składało się z baletu do muzyki Fryderyka Chopina (Impromptu Fantaise oraz cykl Nocturna, czyli pięć nokturnów i Mazurek a-moll, z 1976 r.); czeskiej propozycji Panna iśmierć (choreografia: Pavel Šmok, muzyka: Karel Odstrčil, widzowie ŁSB widzieli ten balet dwa lata wcześniej w wykonaniu Praskiego Baletu Kameralnego ${ }^{39}$ ) oraz z najgoręcej oczekiwanego przez młodzież szczelnie zapełniającą w czasie spektaklu wszystkie schody Teatru Wielkiego - kolażu Yesterday, kompilacji fragmentów dwunastu utworów zespołu The Beatles ${ }^{40}$. Spektakl realizował wprowadzoną przez Drzewieckiego zasadę składania wieczoru baletowego z dzieł o zróżnicowanych stylach, konwencjach i technice wykonawczej. Ostatnia wizyta artysty na łódzkim festiwalu przypadła na rok 1985 (VIII ŁSB), kiedy to pokazal tu swoje najnowsze prace: Ad Matrem - Psalm do kompozycji Henryka Mikołaja Góreckiego, Ostatnia niedzielę z muzyką Józefa Skrzeka, Popołudnie wg preludium Popotudnie fauna Claude’a Debussy'ego oraz Lep na muchy z muzyką Zygmunta Koniecznego. Przez 15 lat obecności Drzewieckiego na ŁSB większość spotkań z jego twórczością budziła prawdziwy entuzjazm. Doceniano rewolucyjny styl choreografii, wyrafinowanie współczesnych technik tańca, znaczeniową motywację ruchu. Zwracano uwagę na oryginalność koncepcji inscenizacyjnych

37 Zob.: XL. Polski Teatr Tańca wczoraj i dziś, audio-video performance w 10 odcinkach: Krzesany i inne tańce, red. Jagoda Ignaczak, PTT Poznań 2012/2013, s. 8.

38 Ewa Pankiewicz, Powrót tańca, „Odgłosy. Tygodnik Społeczno-Kulturalny” 1981, nr 25, s. 9, http://bc.wimbp.lodz.pl/dlibra/publication/67456?tab=1 (dostęp: 15.07.2016).

39 Zob. Jerzy Kwieciński, VII Łódzkie Spotkania Baletowe, „Odgłosy. Tygodnik Społeczno-Kulturalny” 1983, nr 22, s. 9, http://bc.wimbp.lodz.pl/dlibra/ publication?id=67546\&tab=3 (dostęp: 14.06.2016).

40 Prapremiera światowa: 30 XI 1981 w Sofii, w wykonaniu bułgarskiego zespołu tańca współczesnego Arabeska, premiera poznańska w 1982 roku. Drzewiecki był także twórcą kostiumów i współtwórcą scenografii do widowiska. 
utworów, ich zamysł interpretacyjny odpowiadający współczesnemu odczuwaniu świata i efektowne opracowania scenograficzne. Festiwalowa publiczność oklaskiwała wyjątkowy kunszt tancerzy Teatru, wśród nich tak wybitnych jak Olga Sawicka (jako primabalerina Opery Poznańskiej), Emil Wesołowski, Przemysław Śliwa, Roma Juszkat, Lubomira Wojtkowiak, Hanna Staszak, Arkadiusz Duch, Anna Deręgowska, Jacek Sołecki. Jedynie ostatnia wizyta w roku 1985 nie została dobrze przyjęta - tak przez krytykę, jak i przez widzów. Audytorium wygwizdało spektakl Ostatnia niedziela, będący swoistą interpretacją Holokaustu. Jak notował relacjonujący festiwalowe wydarzenia Jerzy Kwieciński: „Zdarzyło się to w naszych spotkaniach baletowych po raz pierwszy"41. Można przypuszczać, że także ten incydent przyczynił się do przedwczesnego zamilknięcia artysty. W roku 1987 Drzewiecki przechodzi na emeryturę, a dyrekcję naczelną i artystyczną PTT-BP oraz przede wszystkim kontynuację jego dzieła podejmuje rok później Ewa Wycichowska, która w kolejnych latach gościła z poznańskim zespołem na prawie wszystkich Spotkaniach, aż do XXII ŁSB w 2013 roku.

Jakość i poziom dwóch pierwszych Biennale były tak wysokie, że aby im sprostać także w kolejnych edycjach $\succeq S B$ organizatorzy musieli sięgać po najznakomitszych współczesnych artystów, którzy często przedstawiali tu nieoglądane wcześniej na polskich scenach style i techniki tańca. Wytworzył się tym samym pewien paradoks: scena, mająca służyć podniesieniu prestiżu miasta i dostarczeniu rozrywki zapracowanym łodzianom (zdaniem komunistycznych władz centralnych w sposób stanowczo przekraczający miarę...), stawała się ostoją nowoczesnej, elitarnej i wysublimowanej sztuki, ściągającej do Łodzi rzesze jej odbiorców. Ponieważ sława festiwalu w latach 70. i 80. rosła, ogromną widownię Teatru Wielkiego, obok znawców i wielbicieli tańca, wypełniały także, z pobudek nieco snobistycznych, tłumy młodzieży oraz - spragnionych światowych klimatów - mieszczan. Jak zauważył Kaszyński, ta „[...] publiczność jest w swej masie oportunistyczna, [...] uparcie chce pozostać w kręgu sentymentalnej i romantycznej mitologii, pragnie patrzeć na metamorfozy dziewic w łabędzie, przysłuchiwać się szeptom nimf i rusałek, błędnych rycerzy [ ... ]"42. Spotkania, jeśli nawet starały się zadośćuczynić także i takim oczekiwaniom widowni, to jednak nie rezygnowały z dbania o wysoki poziom każdej odmiany prezentowanej tu sztuki tańca.

Już na kolejnych III ŁSB (1972) Teatr Wielki gościł m.in. słynny Ballet Rambert, najstarszy nieprzerwanie działający balet w Wielkiej Brytanii (od

41 Jerzy Kwieciński, VIII Eódzkie Spotkania Baletowe, „Odgłosy. Tygodnik Społeczno-Kulturalny” 1985, nr 23, s. 9, http://bc.wimbp.lodz.pl/dlibra/ publication?id=67626\&tab=3 (dostęp: 20.08.2016).

42 Stanisław Kaszyński, Święto baletu... 
roku 1987 pod nazwą Rambert Dance Company), który powstał z inicjatywy polskiej emigrantki Marie Rambert, tancerki, wspóltwórczyni nowoczesnego baletu angielskiego ${ }^{43}$, promotorki wielu najlepszych choreografów. To dzięki jej inspiracji powstawały dzieła: Fredericka Ashtona, Antony'ego Tudora, Normana Morrice’a, a także światowej sławy młodszych choreografów, m.in. Christophera Bruce'a (kierował grupa podczas wizyty Ballet Rambert na III ŁSB) i Wayne’a McGregora (odwiedził Łódź w czasie jubileuszowych XX ŁSB w 2009 r.). Z powodu zaawansowanego wieku (w roku 1972 miała 84 lata) artystka nie przyjechała do Łodzi, ale zespół przywiózł taśmę z nagraniem jej przesłania dla festiwalu, wygłoszonego nienaganną polszczyzną ${ }^{44}$. Ballet Rambert pokazał aż osiem dzieł o bardzo zróżnicowanej poetyce. Obok groteskowych żartów tanecznych w programie dwudniowych występów znalazł się np. utwór Embrace Tiger and Return to Mountain, którego nazwa i charakter nawiązywały do praktyki T'ai-Chi, a także zupełnie odmienna w klimacie choreografia do muzyki Krzysztofa Pendereckiego. Dwudziestoosobowa grupa ukazała różnorodność technik oraz stylów tanecznych i - podobnie jak Ballet du XX-e siècle - zachwyciła kunsztem tancerzy, uchodzących za jednych z najlepszych na świecie. Jak podkreślał dyrektor ŁSB Stanisław Dyzbardis: „, [... ] wizyta Béjarta i Rambert to było baletowe trzęsienie ziemi. Nigdy wcześniej łódzka publiczność nie miała kontaktu ze sztuką baletową na takim poziomie" 45 .

W czasie III Spotkań zaprezentowano w sumie cztery zespoły zagraniczne i cztery polskie, a wśród nich Balet gospodarzy, który przedstawił m.in. Zielony stót. Taniec śmierci, najsłynniejsze dzieło Kurta Joossa, z muzyką Fryderyka A. Cohena. W Wielkim choreografię utworu przygotowała córka Joossa - Anny Markard, ale sam Jooss przyjechał do Łodzi i osobiście dokończył powstawanie tej polskiej prapremiery swego dzieła. W roli Dziewczyny wystąpiła Ewa Wycichowska, solistka Teatru Wielkiego, dla której spotkanie z Joossem i ta kreacja miały decydujące znaczenie dla głębokiego zainteresowania się formą teatru tańca 46 .

43 W 1920 roku Rambert otworzyła w Anglii własną szkołę baletową. Od 1935 roku jej zespół przyjął nazwę Ballet Rambert. W pracach zespołów Marie Rambert brali udział najwybitniejsi tancerze, m.in. Tamara Karsawina, Leon Wójcikowski, Alicia Markova, Agnes de Mille, zob.: Tacjanna Wysocka, Dzieje baletu ..., s. 218-220; zob. też: Wojciech Klimczyk, Wizjonerzy ..., s. 44.

44 Zob.: Teresa Wojciechowska, III Łódzkie Spotkania Baletowe, „Odgłosy. Tygodnik Społeczno-Kulturalny” 1972, nr 24, s. 1, http://bc.wimbp.lodz.pl/dlibra/ publication?id=68381\&tab=3 (dostęp: 15.10.2016).

45 Stanisław Dyzbardis, Monika Wasilewska, Wierzę w site...

46 Zob.: Małgorzata Andrzejewska-Psarska, Więcej niż taniec. Rozmowy z Ewa Wycichowska, Polskie Wydawnictwo Muzyczne, Warszawa 2003, s. 17. 
Jak widać, proporcje między zespołami obcymi a rodzimymi zaczęły się wyrównywać, a nawet dochodziło do swego rodzaju próby sił. Na III ŁSB doskonały francuski teatr tańca Josepha Lazziniego zaprezentował m.in. Cudownego Mandaryna Bartóka, spektakl przygotowany we współpracy z Teatrem Wielkim w Warszawie (ze Stanisławem Szymańskim w roli tytułowej). Tymczasem Drzewiecki - przypomnijmy - na te same Spotkania także przywiózł swojego Cudownego Mandaryna, wielokrotnie później powtarzanego na całym świecie. I to poznański spektakl cieszył się w Łodzi większym uznaniem.

Kolejne edycje Biennale pozwoliły uwyraźnić jego charakter jako przeglądu, który spełnia kilka funkcji. Przede wszystkim było to programowe: „upowszechnianie sztuki baletowej i aktualnych osiągnięć choreograficznych". Ponieważ sięgnięto po „osiągnięcia” rzeczywiście wybitne, przesądziło to o poziomie festiwalu, a nawet o uczynieniu z wydarzenia swoistej enklawy nowoczesności i niezależności w sztuce. To tutaj pojawiały się zespoły prezentujące najnowsze formy tańca, innowacyjne techniki ruchu i style wykonawcze. To tu można było obejrzeć pierwsze polskie teatry tańca. Publiczność ŁSB doświadczała wyjątkowych wzruszeń estetycznych, ale jednocześnie bardzo intensywnej edukacji dotyczącej ważnego obszaru współczesnej sztuki.

Trzeba jednak pamiętać, że Spotkania, podobnie jak wszystkie wydarzenia artystyczne w PRL-u, były silnie uwarunkowane kontekstem polityczno-społecznym. Repertuary festiwalowe musiały uwzględniać występy przedstawicieli krajów socjalistycznych. Regularnie pojawiały się na ŁSB teatry z NRD (Lipsk), ZSRR (Tallin, Leningrad, Perm, Moskwa), a także grupy białoruskie, estońskie, węgierskie, czechosłowackie. Oczywiście, bywały wśród nich zespoły dobre, a nawet świetne, zachwycał kunszt tancerek i tancerzy, szczególnie reprezentujących tzw. rosyjską szkołę baletu. O popisie na III ŁSB moskiewskiego zespołu Baletu Klasycznego pod kierownictwem Jurija Żdanowa Teresa Wojciechowska pisała: „To taniec doprowadzony do perfekcji, to wirtuozowskie popisy sztuki baletowej $[\ldots]$ ”47. Bywały też w gronie wizytujących Łódź „bratnich teatrów” znakomite nowoczesne zespoły taneczne, jak choćby (występujący na VII i VIII ŁSB) węgierski Győri Balett, czyli kompania założona przez wybitnego tancerza - Ivána Markó, który osiem lat tańczył w zespole Béjarta. W roku 1983 zespół przywiózł spektakl Spotkanie z Ivánem Markó, a w jego ramach widowisko Cień Don Juana (Richard Strauss), po którym rozentuzjazmowana publiczność Wielkiego zgotowała artystom kilkudziesięciominutową (!) owację. Jednak rangę i nadzwyczajny status tódzkiego Biennale - pomimo intensywnego forsowania w polskim balecie osiągnięć szkoły radzieckiej - ustalały przede wszystkim występy kilkunastu najwybitniejszych zespołów z Zachodu oraz wyjątkowe prace choreograficzne,

47 Teresa Wojciechowska, III Łódzkie..., s. 8. 
zarówno zagraniczne, jak i rodzime. Konieczność włączania do programów ŁSB zespołów z bloku wschodniego, najczęściej z ich bieżącym repertuarem, utrudniała klarowne artystyczne sprofilowanie Spotkań organizowanych w latach 60.,70. i 80. XX wieku. Choć trzeba też zauważyć, że do takich prób profilowania ŁSB dochodziło niezwykle rzadko. Przymus uwzględniania konkretnych teatrów przesądzał też o nierównym poziomie festiwalowych propozycji. Ironia losu polegała bowiem na tym, że w czasach PRL-u festiwal, jako impreza nadzwyczaj prestiżowa, był tak mocno dotowany przez władze lokalne i centralne, że stać go było na zapraszanie pierwszorzędnych gwiazd światowego baletu, których kunszt zaćmiewał wysiłki artystów z krajów realnego socjalizmu. Wraz ze zmianą ustroju i powstaniem nowych warunków pracy możliwości finansowe $E S B$ - mimo wielu starań organizatorów - ogromnie zmalały.

Niezależnie jednak od okoliczności zewnętrznych, bywały festiwale bardzo wyraziste, przede wszystkim te, które jednak zostały sprofilowane i konsekwentnie poświęcone wybranemu zjawisku tanecznemu, jak na przykład X ŁSB zorganizowane w roku 1989, które zyskały spoistość dzięki obchodom jubileuszu Biennale oraz - przede wszystkim - jako efekt uroczystej organizacji setnej rocznicy urodzin Wacława Niżyńskiego. $Z$ tego powodu Teatr Wielki w Łodzi wystawił, na inaugurację Spotkań, wieloczęściowy Wieczór Baletowy - Wacław Niżyński in memoriam; Polski Teatr Tańca - Balet Poznański, w pierwszym sezonie dyrektorowania tu Wycichowskiej ${ }^{48}$, przygotował spektakl Niżyńskiemu - une soirée; zaś Teatr Wielki w Warszawie zaprezentował siedmioobrazowy Wieczór Baletowy pt. Nasz Niżyński. Przedstawienia, nawiązując do twórczości Niżyńskiego, podejmowały interpretację dwudziestowiecznych praktyk tanecznych i choreograficznych. Towarzyszyły im XXXI Łódzkie Warsztaty Operowe Wactaw Niżyński oraz sesja popularnonaukowa: Wactaw Niżynski - życie, dorobek artystyczny - symbol sztuki baletowej XX wieku ${ }^{49}$. Takie sprofilowane edycje festiwalu były sporadycznie organizowane także później (np. w roku 2015, gdy poświęcono Spotkania mistrzom współczesnej choreografii), lecz nie przekształciło się to nigdy w stałą cechę wydarzenia. Podobnie prowadzenie w ramach festiwalu usystematyzowanej refleksji naukowej nad sztuką tańca - a takie

48 Artystka jednocześnie: stworzyła choreografię do Święta wiosny w łódzkim TW i tańczyła Szeherezadę w dramacie choreograficznym Nikołaja Rimskiego-Korsakowa.

49 Program: 20.05-10.06, X Łódzkie Spotkania Baletowe’89, Teatr Wielki w Łodzi, red. programu Tomasz Graczyk, Cyfrowe Muzeum Teatru Wielkiego w Łodzi, http://www.cyfrowemuzeum.operalodz.com/wp-content/uploads/2018/04/ TWL_LSB_PR_X.1989XX.pdf (dostęp: 18.06.2017). Zob też: Adam Domański, Jubileusz sztuki tańca, „Życie Literackie” 1989, nr 21, s. 6, http://mbc.malopolska.pl/ dlibra/plain-content?id=13572 (dostęp: 15.06.2016). 
bardzo cenne wydarzenia towarzyszyły wczesnym $Ł S B$ - przez lata nie zyskało trwałości i coraz częściej zdarzało się jedynie okazjonalnie. Dopiero ostatnie Biennale przyniosły spotkania dyskusyjne $\mathrm{z}$ artystami i realizatorami spektakli prezentowanych podczas Spotkań.

Dzięki istnieniu Biennale Teatr Wielki w Łodzi bardzo rozwinął się artystycznie. Powstała tradycja inaugurowania $Ł S B$ premierą przygotowywaną przez zespół baletowy Wielkiego, co każdorazowo stanowiło duże wyzwanie. Także bieżący repertuar widowisk tanecznych coraz częściej powstawał we współpracy z wybitnymi indywidualnościami światowej sceny baletowej. Spektakularnego przykładu takiej wspólpracy dostarcza polska prapremiera baletu Gajane do muzyki Arama Chaczaturiana (21 XI 1975) ${ }^{50}$, którą przygotował Boris Ejfman (libretto, choreografia i inscenizacja), dziś uznany za jednego z najświetniejszych współczesnych twórców sztuki tańca. W przedstawieniu stanowiącym debiut na zagranicznej scenie i jednocześnie wielki sukces młodego wówczas choreografa (na premierę przyjechał sam kompozytor), rewelacyjnie zatańczyli soliści Teatru Wielkiego: Ewa Wycichowska w roli tytułowej i Kazimierz Wrzosek w roli Giko ${ }^{51}$. Łódzka Gajane w choreografii Ejfmana, jako jedna z najlepszych premier TW, została pokazana także na VI ŁSB (1981). Natomiast prowadzony od 1977 roku przez artystę Leningradzki Teatr Baletu Współczesnego, późniejszy Sanktpetersburski Teatr Baletu Borisa Ejfmana, wystąpił na Spotkaniach jeszcze wielokrotnie, prezentując tu znakomite choreografie swojego założyciela. Na IX ŁSB (1987) były to aż cztery widowiska: Idiota (do VI Symfonii Piotra Czajkowskiego), Mistrz i Matgorzata (Andriej Pietrow), Legenda (Leonid Kogan), Podporucznik Romaszow (Walery Gawrilin). W roku 1993 (XII ŁSB) - czyli już po triumfalnych występach zespołu Ejfmana w Paryżu (1988) i zyskaniu przez niego światowej sławy - publiczność Biennale zobaczyła Iluzje (Carolin Petit), Requiem (Mozart) i Therese Raguin (Bach, Mahler, Alfred Schnittke). Ostatnia z festiwalowych wizyt artysty przypadła na rok 2005, kiedy to w trakcie XVIII ŁSB przedstawił spektakl Musagète do muzyki Bacha i Czajkowskiego. Przedstawienie przygotowane zostało przez Ejfmana z artystami Teatru Wielkiego - Opery Narodowej na stulecie urodzin twórcy neoklasycznego baletu - George’a Balanchine’a (w ramach przedstawienia Balanchine i muzy). WŁodzi dzieła choreograficzne Ejfmana pojawiały się jednak nie tylko w czasie Spotkań. Na scenie Wielkiego można było w ciągu ośmiu lat zobaczyć także: Braci Karamazow (1996, Wagner, Musorgski, Sergiusz Rachmaninow), słynną Giselle Rouge (1997, Czajkowski, Bizet, Adam,

50 Zob.: hasło: 'Gajane. Teatr Wielki. Łódź, wortal: Encyklopedia Teatru Polskiego, http://encyklopediateatru.pl/przedstawienie/7555/gajane (dostęp: 16.08.2016).

51 Stanisław Dyzbardis, Nasze czterdziestolecie (garść wspomnień), [w: ] Teatr Wielki w Łodzi 1967-2007, red. Tomasz Graczyk, Łódź 2006, s. 12. 
Schnittke), Don Juana \& Moliera (2003, Mozart, Hector Berlioz). Nawet jubileusz 25-lecia swojego zespołu artysta świętował w 2002 roku w Łodzi - wzruszony charakterem wydarzenia, przyjął bowiem zaproszenie na Festiwal Dialogu Czterech Kultur i pokazał na nim Rosyjskiego Hamleta (Ludvig van Beethoven, Mahler) oraz uroczystą baletową Galę. Łódź nie tylko patronowała narodzinom prawdziwej gwiazdy współczesnej sztuki tańca, ale i mocno angażowała się w rozwój jego kariery, co jednocześnie umacniało pozycję i prestiż Biennale jako instytucji.

Jeszcze intensywniejsze relacje z łódzką sceną, Spotkaniami i samym miastem połączyły nowozelandzkiego choreografa Graya Veredona, który przygotowat w Wielkim szereg swoich premier: Wolfganga Amadeusa (Mozart, choreografia, inscenizacja, libretto - Veredon, prapremiera 16 V 1987, wznowienie 2002), Sen nocy letniej (Felix Mendelssohn, 1985), Romea i Julię (Hector Berlioz, 1992), Purytanów (Vincenzo Bellini, 2002). Powstał tu także „łódzki tryptyk baletowy”, będący dowodem szczególnego zafascynowania artysty miastem: Ziemia obiecana (muzyka: Franz von Suppé i Michael Nyman) na otwarcie XV ŁSB (1999), Kobro, na inaugurację XVII ŁSB (2003) i jubileusz 35-lecia festiwalu oraz Kolor zótty inicjujący XVIII edycję ŁSB w 2005 roku (obydwa przedstawienia do muzyki Sławomira Kulpowicza) ${ }^{52}$.

Spośród innych wybitnych choreografów współpracujących z łódzkim Teatrem Wielkim, i tym samym stanowiących inspirację dla organizatorów Biennale, trzeba wymienić przynajmniej: Ericha Waltera, Germinal Casado, Antala Fodora, Lorkę Massine’a, Giorgia Madię, Teresę Kujawę, Jerzego Makarowskiego, Emila Wesołowskiego, Ewę Wycichowską.

Oznaką rosnącego znaczenia ŁSB była nie tylko współpraca z mistrzami współczesnej choreografii, ale także zwiększająca się liczba biorących w nich udział wybitnych zespołów. W roku 1981 na VI Biennale - zorganizowanym po jedynej w jego historii pięcioletniej przerwie (zawieszenie Spotkań spowodowało też, że tryb festiwalu przeszedł z lat parzystych na nieparzyste, i tak jest do dnia dzisiejszego) - wystąpiło już 10 zespołów i liczba ta powtarzała się przez kolejne dwie edycje. Najliczniejsze było (do roku 2015) XI Biennale w 1991 roku, kiedy na scenie Wielkiego wystąpiło aż 11 zespołów. ŁSB nabierało cech festiwalu gwiazd i presja ciągłego zwiększania liczby zapraszanych gości zaczynała nawet grozić przeładowaniem programu.

Odwiedzające Łódź renomowane zespoły taneczne prezentowały tu bardzo różne techniki i style tańca: klasykę, neoklasykę, modern, postmodern,

52 Zob.: Małgorzata Andrzejewska-Psarska, Tribute to Łódź, „Gazeta Łódzka” 1999, nr 114, http://www.e-teatr.pl/pl/artykuly/255462,druk.html (dostęp: 15.07.2016); Michał Lenarciński, XVIII Łódzkie Spotkania Baletowe - Andaluzyjski temperament, „Dziennik Łódzki” 2005, nr 115. 
contemporary, jazz dance, demi, taniec fizyczny, hip-hop, a nawet: break dance, capoeirę, styl popping czy taneczną akrobatykę, ale także na przykład pantomimę. O specyfice łódzkiego festiwalu nie przesądzał zatem rodzaj prezentowanego tu tańca/ruchu czy sposób namysłu nad nim - co zaczynało być dostrzegalną tendencją wśród nowo powstających przeglądów sztuki tańca - lecz właśnie wielka różnorodność propozycji. I tak na przykład, w czasie dwóch kolejnych edycji - na VII i VIII ŁSB - łodzianie mogli oglądać „monodramy, czyli pełnospektaklowe widowiska pantomimiczne" 53 Wrocławskiego Teatru Pantomimy Henryka Tomaszewskiego. W roku 1983 ten świetny polski tancerz (uczeń m.in. Feliksa Parnella), mim, a także choreograf, reżyser i inscenizator, twórca „teatru ruchu”, pokazał Rycerzy Króla Artura (premiera 1981, muzyka Wagner, Gordon Giltrap, Johann Nepomuk Hummel, Bogdan Dominik), a na kolejnym Biennale - Syna marnotrawnego (premiera 1984, collage muzyczny). Obydwa widowiska były już jednak dziełami „późnego Tomaszewskiego”, w którego sztuce głęboka taneczna refleksja nad istotą pantomimy i jej możliwościami wyrazowymi ustępowała przedstawieniom, niezwykle efektownym wprawdzie, lecz skupionym raczej na budowaniu bogatej plastycznie i muzycznie syntetycznej wizji scenicznej niż nad namysłem nad sposobami artykulacji samego ruchu. Pozostawały więc one w pewnym oddaleniu od tego, co dotyczyło strategii artystycznych rozwijanych w światowej sztuce tańca, podobnie jak osobną jakość stanowiło np. flamenco, chętnie zapraszane na $Ł S B$ i uwielbiane przez widzów. $Z$ wielkimi sukcesami demonstrowały kulturę flamenco w Łodzi sławne zespoły: Ballet Cristina Hoyos i Ballet Flamenco de Andalucia prowadzone przez Christinę Hoyos, „królową flamenco”, słynną tancerkę zespołu Antonio Gadesa i gwiazdę filmów Carlosa Saury. Hoyos dzięki efektownemu występowi na XVII festiwalu (2003) zawładnęła emocjami łódzkiej publiczności: „Chropowaty głos, trudne rytmy, stukot obcasów, napięcie emanujące $\mathrm{z}$ tancerzy sprawiły, że widownia poddała się transowi i niemal tańczyła razem z Hiszpanami" 54 . Ku satysfakcji widzów organizatorzy $€ S B$ zaprosili artystkę także na kolejne, XVIII Spotkanie, na które przywiozła zupełnie nowy (zaledwie dwumiesięczny) spektakl Viaje al sur (w swojej choreografii, do muzyki Joségo Luisa Rodrigueza).

53 Karol Smużniak, Teatr milczenia i dramat przemilczeń, Wyższa Szkoła Pedagogiczna im. Tadeusza Kotarbińskiego, Zielona Góra 1996, s. 9; por. też idem, Teatr pantomimy Henryka Tomaszewskiego: prolegomena do teorii teatru pantomimy, Oficyna Wydawnicza Uniwersytetu Zielonogórskiego, Zielona Góra 2004.

54 Małgorzata Andrzejewska-Psarska, Łódź żyła tańcem, „Gazeta Wyborcza - Łódź” (26 maja 2003), http://lodz.wyborcza.pl/lodz/1,35135,1498802. html? disableRedirects=true (dostęp: 16.08.2016). 
Jaki zatem obraz tańca współczesnego wytwarzał - tak zawsze opiniotwórczy - łódzki przegląd, jedno z najlepszych tanecznych biennale w Europie? Próbując wyłuskać zjawiska o najdonioślejszym znaczeniu dla prezentacji dynamiki przemian sztuki tańca, wśród mnogości propozycji pojawiających się w czasie półwiecza trwania łódzkich Spotkań trzeba przedstawić jeszcze kilka występujących tu zespołów. Jak niegdyś grupa Maurice’a Béjarta, były to bowiem kompanie, które decydowały o poziomie i renomie $€ S B$, czyniąc z niego forum wymiany myśli choreograficznej i przestrzeń konfrontacji twórczości tancerek i tancerzy. Pamiętając, że współczesne grupy taneczne najczęściej łączą w swojej praktyce wykonawczej różne techniki tańca, warto jednak pokusić się o refleksję nad ich sztuką wedle podkreślanej przez krytyków cechy ŁSB - stylistycznego spolaryzowania prezentowanego tu repertuaru. Bardzo hasłowo rozumiane - klasyka i współczesność, wyznaczały dwa bieguny emocji i gorących sporów, tak festiwalowej publiczności, jak i krytyki.

Wśród zespołów najbliższych technice klasycznej dwukrotnie odwiedzil festiwal słynny Ballet Nacional de Cuba, który założyła - i przyjechała z nim do Łodzi - kubańska primaballerina assoluta, z sukcesami uprawiająca także choreografię i pedagogikę tańca - Alicia Alonso. Na VI ŁSB (1881), narodowy zespół z Kuby pokazal charakterystyczne dla swojej twórczości utwory żywiołowo interpretujące zjawiska natury: Owoce i rzeczywistość, Ucieczka, Trapiz, Przyplyw morski, Flora, Plasmasis 55 . Natomiast na X ŁSB (1989) Kubańczycy występowali aż przez trzy wieczory i przedstawili w Łodzi 10 utworów ${ }^{56}$. A sama Alonso - największa romantyczno-klasyczna balerina doby obecnej (jak określiła artystkę Tacjanna Wysocka ${ }^{57}$ ) - wówczas już licząca lat (zależnie od źródeł...) prawie lub ponad 70 - tańczyła na pointach m.in. rolę Afrodyty w balecie Amaris do muzyki elektronicznej specjalnie dla niej napisanej ${ }^{58}$. I wzbudziła prawdziwy entuzjazm festiwalowej publiczności ${ }^{59}$, która nieodmiennie od lat właśnie takie widowiska, tworzone przez pierwszorzędnych artystów, obdarza najwyższym uznaniem.

Stonowany rodzaj ekspresji scenicznej reprezentowały najszacowniejsze klasyczne europejskie zespołu baletowe, których wizyty były niewątpliwie wydarzeniami nobilitującymi łódzkie Spotkania. Na IX festiwal (1987) przyjechał

55 Zob.: Ewa Pankiewicz, Powrót...

$56 \mathrm{~W}$ nieco zmienionym układzie niż widniejący w programie wydarzenia, por.: Program teatralny: X Łódzkie Spotkania Baletowe’89... ; Adam Domański, Jubileusz...

57 Tacjanna Wysocka, Dzieje baletu ..., s. 267.

58 Zob.: Adam Domański, Jubileusz...

59 Zob.: ibidem; Jerzy Kwieciński, X Łódzkie Spotkania Baletowe. Ostatni „krajowcy” i goście z Kuby, „Odgłosy. Tygodnik Społeczno-Kulturalny” 1989, nr 25, s. 9, http:// bc.wimbp.lodz.pl/dlibra/publication/67915?tab=1 (dostęp: 15.08.2016). 
z Wielkiej Brytanii sam Sadler's Wells Royal Ballet. Warto przypomnieć, że to balet o statusie brytyjskiego baletu królewskiego, który wywodzi się z zespołu tanecznego Vic-Wells Ballet ${ }^{60}$, stworzonego w latach 30 . XX wieku przez tancerkę, choreografkę i współtwórczynię narodowego baletu angielskiego i irlandzkiego - Ninette de Valois. Zespół w swoich dziejach parokrotnie przekształcał się, ewoluował, łączył z innymi grupami, a po utracie sceny w teatrze Old Vic i zbudowaniu nowego teatru Sadler's Wells, przybrał nazwę Sadler's Wells Ballet. Później został rezydentem Royal Opera House w Covent Garden i współtworzył The Royal Ballet, aż w roku 1956 - rozkazem królowej Elżbiety II - została utworzona jedna narodowa instytucja artystyczna - właśnie pod nazwą Sadler's Wells Royal Ballet ${ }^{61}$. A zatem, odwiedził łódzki festiwal jeden z najważniejszych europejskich baletów, zespół działający pod protektoratem brytyjskiej monarchini, któremu artystycznie patronowały legendarne autorytety: obok Dame Ninette de Valois - m.in. Alicia Markova, Frederick Ashton czy Margot Fonteyn. Sadler's Wells pokazał w Łodzi Królowa Śniegu (wg Modesta Musorgskiego) do muzyki opracowanej przez Bramwella Toveya, z choreografią Davida Bintleya (obaj należą dziś do czołówki brytyjskich twórców). Występ stanowił część - pierwszego w dziejach Sadler's Wells - tournée po ówczesnych krajach socjalistycznych: Niemieckiej Republice Demokratycznej, Czechosłowackiej Republice Socjalistycznej, Ludowej Republice Bułgarii i Polskiej Rzeczpospolitej Ludowej. Ów wyraźnie edukacyjny charakter wizyty ujawnił się w stylu przedstawienia, które było: „... ] klarowne i przystępne, o czytelnej symbolice, a nade wszystko posługujące się tradycyjnymi [...] środkami wyrazu"62, co satysfakcjonowało znaczną część publiczności, a nawet krytyki. Poczucie obcowania z elitą sztuki tańca pozostało w pamięci widzów ŁSB bardzo silne przez długie lata, mimo że odwiedzający Teatr Wielki zespół składał się z artystów tworzących swego rodzaju „wydzieloną scenę objazdową" 63 .

Cztery lata później, na XI festiwalu (1991), ŁSB gościły Stuttgarter Ballett, zespół od 1961 roku prowadzony przez Johna Cranko, jednego z najlepszych baletmistrzów i choreografów XX wieku. Cranko był adeptem szkoły Sadler's Wells i zaczynał twórczość choreograficzną w latach 40. pod okiem de Valois, by

60 Zob. Tacjanna Wysocka, Dzieje baletu ..., s. 220-224; Andrzej Chodkowski, Encyklopedia muzyki, Państwowe Wydawnictwo Naukowe, Warszawa 1995.

61 Tacjanna Wysocka, Dzieje baletu ..., s. 220-232.

62 Ibidem.

63 Zob.: Jerzy '.'. ', IX Łódzkie Spotkania Baletowe. Sadler's Wells, „Odgłosy. Tygodnik Społeczno-Kulturalny” 1987, nr 22, s. 8, http://bc.wimbp.lodz.pl/dlibra/ publication/67809?tab=1 (dostęp: 10.07.2016). 
później rozwijać talent współpracując ze światowej sławy zespołami i tancerza$\mathrm{mi}^{64}$. Stuttgartczycy przedstawili w Łodzi Poskromienie złośnicy według Williama Shakespeare'a z muzyką Kurta-Heinza Stolzego (wg Domenica Scarlattiego), czyli jedną z ostatnich prac choreograficznych Cranko, zmarłego nagle w 1973 roku. Przedstawienie dobrze reprezentowało styl baletowej narracji artysty, łączący perfekcję techniczną tancerzy z wyrazistą i dramatyczną grą aktorską. Warto zauważyć, że Cranco uczył się w Sadler's Wells, sam zaś kształcił w Stuttgarter Ballett m.in. Jürgena Heissa, którego widowisko baletowe Gershwin, przygotowane z zespołem Teatru Wielkiego w Łodzi, zamykało XI ŁSB 65 . To jedna z wielu znaczących koincydencji w dziejach łódzkiego festiwalu, krzepnącego instytucjonalnie i coraz częściej oferującego spotkania z twórczością ścisłej światowej czołówki artystek i artystów sztuki tańca.

Spośród nieprzeciętnych zespołów uprawiających klasyczny styl tańca, które odwiedziły Łódź już w XXI wieku, należy przynajmniej wspomnieć o Compania Nacional de Danza z Madrytu, prowadzonej w latach 1990-2011 przez jednego z czołowych dzisiejszych twórców - Nacho Duato66. Aby tańczący do muzyki hiszpańskiej XV i XVI wieku zespół przyjechał na Spotkania w 2005 roku i pokazał tu trzy swoje utwory: Arcángelo, Cautiva, Por vos muero, organizatorzy zabiegali pięć lat 67 .

Takie rarytasy programowe jak występy grupy Duato były niecierpliwie oczekiwane przez festiwalowych koneserów, a tych Biennale wychowało sobie potężną liczbę. Jednak niemałej części widzów ŁSB największych emocji nadal dostarczały tradycyjne dzieła taneczne - na czele z Jeziorem tabędzim Czajkowskiego. Arcydzieło repertuaru baletowego, które w swojej klasycznej petersburskiej wersji choreograficznej - Mariusa Petipy i Lwa Iwanowa - miało premierę w Teatrze Maryjskim ponad 130 lat temu, ciągle jest probierzem technicznej doskonałości tancerzy i tancerek oraz zdolności inscenizatorów. Pragnąc spełnić oczekiwania publiczności i przyjrzeć się współczesnej sztuce interpretacji Jeziora ..., organizatorzy Spotkań, w ciągu zaledwie pięciu edycji festiwalu, zaprosili

64 Zob. Wojciech Klimczyk, Wizjonerzy ..., s. 188-189; 'John Cranko. Choreograf', strona Teatru Wielkiego - Opery Narodowej w Warszawie, https://teatrwielki.pl/people/john-cranko/ (dostęp: 23.09.2016).

65 Zob.: Gershwin (wieczór baletowy), wortal: http://www.e-teatr.pl/pl/ realizacje/11411,szczegoly.html (dostęp: 23.08.2016).

66 Zob. strona zespołu: https://cndanza.mcu.es/en/147-archive/archive-cnd/ nacho-duato-archive-90-11/archive-repertoire-nacho-duato-90-11/2808-nacho-duato-biography (dostęp: 12.08.2016).

67 Zob. Stanisław Dyzbardis, Łódź tańczy..., „Kalejdoskop” 2005, nr 5; wortal: http://www.e-teatr.pl/pl/artykuly/11997,druk.html (dostęp: 20.08.2016). 
aż cztery teatry z ich wersjami tego utworu. Były to: Balet „Bolszoj” z Białorusi (XVI ŁSB, 2001), Państwowy Akademicki Teatr Opery i Baletu im. Modesta Musorgskiego z Sankt Petersburga (XVIII ŁSB, 2005), Korea National Ballet Company (XIX ŁSB, 2007) oraz gospodarze - Teatr Wielki w Łodzi (XX ŁSB, 2009). Rzut oka na te inscenizacje ujawnia charakter polityki impresaryjnej łódzkiego festiwalu i diagnozuje jego ewolucję.

Przedstawienie teatru „Bolszoj” (redakcję choreografii do Jeziora ... opracował Walentin Jelizariew) reprezentowało ów nurt silnie obecnej na Spotkaniach „klasyki klasyki”68, która może budzić uznanie, gdy oferowana jest w perfekcyjnym wykonaniu, ale bardziej wymagających widzów zazwyczaj nuży i nieodparcie bawi anachronicznością, gdy np.: „Na tle malowanej wody suną plastikowe łabędzie ze swym plastikowym odbiciem [...]"69. Edyta Hajduk, recenzentka łódzkiego występu białoruskiego zespołu, formułuje tezę, którą można by odnieść do niemałej grupy klasycznych baletów narracyjnych oglądanych na ŁSB: „Orkiestra gra na żywo, dekoracje i rekwizyty są nierealistyczne, gra aktorska jest przerysowana, a po każdym popisie tancerze podchodzą do rampy, aby się ukłonić. W tego typu teatrze sama wierność tradycji jednak nie wystarcza, można się na nią zgodzić jedynie w wypadku prawdziwej wirtuozerii”70. Ów styl konserwatywnej inscenizacji, ciągle obecny w światowym balecie, pojawiał się także na $€ S B$, lecz coraz rzadziej zyskiwał tu uznanie.

Zespół z Petersburga, prezentujący balet Czajkowskiego cztery lata później, to teatr o długiej tradycji. Zainicjowany został jako Teatr Mały w Leningradzie już w latach 30. XX wieku przez Fiodora Łopuchowa - wybitnego radzieckiego baletmistrza, a także nowatorskiego choreografa. Łopuchow zasłynął z tworzenia nietypowych inscenizacji klasycznych dzieł, w których wykorzystywał bufonadę, śpiew, elementy teatru lalek, operetki i sztuki cyrkowej, co przyniosło mu sławę twórcy współczesnego baletu komediowego w Rosji. Jeszcze jako Teatr Mały (Akademicki) Opery i Baletu w Leningradzie, zespół przyjechał na VIII ŁSB (1985) i pokazał wówczas Makbeta w choreografii Nikołaja Bojarczikowa. Dwadzieścia lat później, już pod nową nazwą - i z St. Petersburga - Balet ponownie odwiedził Łódź, właśnie z Jeziorem ..., w redakcji tego samego artysty. Nie doczekano się jednak wydarzenia artystycznego. Koncepcję ruchu Bojarczikowa zgryźliwie opisał recenzujący przedstawienie Michał Lenarciński: „Holenderski impresario rosyjskiego zespołu przywiózł do Łodzi... 33 urządzenia do udawania łabędzi. [...] Mechanicznie wykonywały kroki, gesty i figury, na ogół

68 Określenie Edyty Hajduk, eadem, Zatańcz to jeszcze raz, „Didaskalia. Gazeta Teatralna” 2001, nr 43/44, s. 81.

69 Ibidem, s. 82.

70 Ibidem. 
równo i bez wdzięku. Za to $\mathrm{z}$ ostentacyjnym wyrazem znudzenia malującym się na frontowej stronie każdego $\mathrm{z}$ urządzeń $[\ldots]^{71}$. Jeśli tym przedstawieniem Teatr pragnął nawiązać do poetyki tańca komediowego Łopuchowa, to śmiech czy irytacja widzów, jakie wzbudzały oglądane sceny, nie wynikały jednak z celowych zamierzeń artystycznych. Łódzka publiczność była już doskonale świadoma, że aby uwspółcześnić Jezioro ..., przekroczyć czy zakwestionować jego kanoniczną postać, trzeba zaproponować spójną i logiczną koncepcję całości. Nawet gdy nowa forma radykalnie przemienia choreografię i styl Petipy/Iwanowa, można osiągnąć doskonały rezultat - jak to się stało na przykład w słynnym minimalistycznym Swan lake, 4 acts Raimunda Hoghe'a z 2005 roku $^{72}$. Niestety, propozycja petersburskiego teatru żadnej spójnej całości nie zbudowała. Festiwalowe prezentacje bywały - jak widać - także zupełnie nietrafione. Ale tak się dzieje w wypadku każdego wielkiego i długotrwałego przedsięwzięcia, na jakie Spotkania wyrosły w ciągu kilkudziesięciu lat. Natomiast edukacyjny potencjał tego wydarzenia okazał się bardzo cenny, co ujawniły już kolejne Biennalowe Jeziora ...

Dla południowokoreańskiego Korea National Ballet Company przyjazd na XIX ŁSB (2007) był pierwszą wizytą w tej części Europy, choć zespół występuje już ponad 40 lat i z sukcesami odbywał tournée po wielu krajach świata ${ }^{73}$. Teatr tak bardzo chciał odwiedzić Spotkania, że sam pokrył koszty przelotu i transportu dekoracji ${ }^{74}$. Zaprezentowane przez nich Jezioro ..., w choreografii Jurija Grigorowicza, spotkało się z entuzjastycznym przyjęciem - tak publiczności (prawie 15-minutowa owacja na stojąco), jak i krytyki. Pisano: „Surowa i wymagająca klasyka w ich wykonaniu stawała się kwintesencją elegancji i lekkości. Podziw wzbudzała także nienaganna precyzja wszystkich tancerzy i niewiarygodna wprost synchronizacja ruchu"75. To właśnie mistrzostwo i talent artystów nieodmiennie wzbudzały na $€ S B$ największy zachwyt, co - planując repertuar - brali pod uwagę organizatorzy.

71 Michał Lenarciński, Urządzenia (nie) wielofunkcyjne, „Dziennik Łódzki” 2005, $\mathrm{nr}$ 123, za: http://encyklopediateatru.pl/artykuly/12871/udawane-labedzie-na-final (dostęp: 18.09.2016).

72 Zob.: np. Anna Królica, Wzbogacenie przez redukcję, https://www.dwutygodnik. com/artykul/2804-wzbogacenie-przez-redukcje.html (dostęp: 30.08.2016).

73 Zob.: Michał Lenarciński, XIX Łódzkie Spotkania Baletowe, „Dziennik Łódzki” 2007, nr 103, za: Łódź. Spotkania Baletowe niebawem, http://encyklopediateatru.pl/artykuly/38568/lodz-spotkania-baletowe-niebawem (dostęp: 18.09.2016).

74 Stanisław Dyzbardzis, Monika Wasilewska, Wierzę w siłe...

75 Michał Lenarciński, XIX Łódzkie Spotkania Baletowe warte są każdych pieniędzy, „Dziennik Łódzki” 2007, nr 133, wortal: http://www.e-teatr.pl/pl/artykuly/40253. html (dostęp: 15.08.2016). 
Jubileuszowe XX Spotkania w roku 2009 otworzyli gospodarze, czyli Teatr Wielki w Łodzi, także prezentacją Jeziora ..., które z Baletem TW przygotował włoski choreograf i reżyser - Giorgio Madia. Artysta świetnie znany był ze swej błyskotliwej kariery tancerza: występował m.in. w Teatro alla Scala; w zespołach Béjarta, w grupach amerykańskich i szwajcarskich; tańczył też z Nuriejewem w czasie jego pożegnalnego tournée po świecie ${ }^{76}$. Już jako choreograf współpracował z wieloma scenami włoskimi, niemieckimi i polskimi - w tym w szczególności z tódzkim Wielkim. Od początku XXI wieku zrealizował tu szereg widowisk: Bolero (2000), Giuseppe! (autorskie fragmenty, 2001), Gershwin Celebration (2001), Śpiąca królewna (2006), Cinderella/Kopciuszek - tym przedstawieniem Wielki inaugurował XIX ŁSB (2007), Opowieści Hoffmanna (2007), Dziadek do orzechów (2008), Chopin wymarzony/ Chopin Imaginare (2015), a także właśnie Jezioro łabędzie (premiera 9 V 2009). Zgodnie z główną zasadą swojej twórczości scenicznej - komicznej gry ze stereotypami - Madia zaproponował dość śmiałą modyfikację klasycznej redakcji utworu, tak pod względem przebiegu muzyki, interpretacji fabuły, jak i modyfikacji stylu i charakteru tańca. Tancerki w rolach łabędzi zachowały tradycyjny wizerunek sylwetek i układ rąk, ale pozbawione zostały point i tańczyły boso, co uczyniło ich ruchy groteskowymi, a taniec niespójnym. Takie - jak nazwał je Jacek Merczyński - „oskubane łabędzie”77 nie porwały łódzkiej publiczności, dobrze już obytej z eksperymentowaniem w sztuce tańca i nieskorej do bezkrytycznego akceptowania ryzykownych pomysłów, nawet gdy są one autorstwa związanego z Teatrem artysty. Nie pomogła uroda scenografii (Bruno Schwengl), umiejętności baletu i orkiestry TW (pod dyrekcją Tadeusza Kozłowskiego), a nawet wdzięk młodziutkich uczennic łódzkiej szkoły baletowej $\mathrm{w}$ pas de quatre.

Na ostatnich z uwzględnianych tu Spotkaniach - XXIII w 2015 roku - widzowie mieli okazję jeszcze raz zobaczyć Jezioro łabędzie, zagrane tym razem jako $L A C$ (skrócony tytul: Le Lac des cygnes), w choreografii Jeana-Christophe’a Maillota i w wykonaniu Les Ballets de Monte Carlo. Zespół powstał w roku 1985 i działa pod patronatem Karoliny, księżnej Hanoweru, księżniczki z dynastii Grimaldich, pragnącej rozwijać tradycje taneczne Monako i spełnić w ten sposób marzenie swojej matki - księżnej Grace Grimaldi (Grace Kelly) ${ }^{78}$. Maillot w 1993 roku objął funkcję dyrektora artystycznego monakijskiego teatru i przygotował tu sze-

76 Zob. np. ‘Giorgio Madia', strona Opery Baltyckiej w Gdańsku, https://operabaltycka.pl/pl/zespol/giorgio-madia (dostęp: 15.07.2016).

77 Zob.: Jacek Marczyński, Oskubane łabędzie, https://www.rp.pl/artykul/303406-Oskubane-labedzie-html (dostęp: 12.07.1016).

78 Zob.: Jean-Christophe Maillot, Les Ballets de Monte-Carlo, la compagnie: 19852015. Trente saisons chorégraphiques des Ballets de Monte-Carlo, Somogy éditions d’Art, 
reg cieszących się dużym uznaniem widowisk: Romea i Julię (1996), Kopciuszka (1999), Śpiąca królewnę (2001), Le Songe (2005), Altro Canto (2006), Fausta (2007). I najnowsze: LAC z roku 2011 oraz autotematyczny spektakl taneczny CHORÉ z 2013 roku $^{79}$. Wszystkie przedstawienia przyczyniły się do wielkiej popularności zespołu w Europie, postrzeganego dziś jako zarazem klasyczny i innowacyjny. Podobny charakter miało przedstawione w Łodzi LAC. Dbając o uwspółcześnienie dzieła, Maillot zaprosił do współpracy Jeana Rouauda - laureata Nagrody Goncourtów z 1990 roku, który opracował libretto. Inscenizacja okazała się nadzwyczaj udana. Jak pisał recenzujący łódzki spektakl Dariusz Pawłowski: „W zadziwiający i precyzyjny sposób Maillot połączył klasykę tańca, z nowoczesnymi estetyką, gustem i tempem; elegancję z bezwzględną, barbarzyńską nawet mocą" ${ }^{80}$. W Wielkim $L A C$ zostało przyjęte długą i gorącą owacją na stojąco, co daje świadectwo, iż patronującą festiwalowi ideę upowszechniania „sztuki baletowej i aktualnych osiągnięć choreograficznych" udało się zrealizować ze znacznym sukcesem edukacyjnym.

Reakcje publiczności na cztery wymienione Jeziora ... dowodzą, że widzowie ŁSB nauczyli się bardzo dobrze odróżniać innowacyjne interpretacje klasycznych dzieł od tych, które - posługując się maską nowoczesności - pozostają $\mathrm{w}$ istocie nieczułe na ich prawdziwe znaczenia i nie potrafią podjąć rzeczywistego dialogu z tradycją. Taki kształceniowy wymiar festiwalu artystycznego wydaje się nie do przecenienia.

Impresaryjnych błędów łatwo uniknąć, zapraszając na festiwal wiodący europejski teatr operowy i baletowy - włoski Teatro alla Scala. W ostatnich latach teatr ten aż dwukrotnie przyjął zaproszenie organizatorów i przyjechał na XXI oraz XXIII ŁSB. W czasie pierwszej wizyty (2011 r.) Zespół Baletowy przedstawił słynną choreografię Balanchine’a - Jewels z 1967 roku, czyli tryptyk: Szmaragdy, Rubiny, Diamenty (Gabriel Fauré, Strawiński, Czajkowski). Widowisko, stanowiące kwintesencję stylu artystycznego mistrza dwudziestowiecznej choreografii, pokazane było w Łodzi wcześniej niż odbyła się jego premiera na rodzimej

Paris 2016, https://issuu.com/baranes/docs/les_ballets_de_monte_carlo.30_ sais/15 (dostęp: 15.07.2016).

79 Maillot ma w dorobku ponad 30 spektakli, spośród których wiele weszło do repertuaru innych znaczących zespołów baletowych. Jest również pomysłodawcą i założycielem festiwalu „Le Chorégraphique”, zob.: ibidem, s. 226.

80 Dariusz Pawłowski, XXIII Łódzkie Spotkania Baletowe. Wspaniały spektakl Les Ballets de Monte Carlo, „Dziennik Łódzki” (26 maja 2015), http://www.dzienniklodzki. $\mathrm{pl} /$ artykul/3876579,xxiii-lodzkie-spotkania-baletowe-wspanialy-spektakl-les-ballets-de-monte-carlo,id,t.html (dostęp: 13.08.2021). 
mediolańskiej scenie ${ }^{81}$. Natomiast w roku 2015 Włosi przywieźli Galę składającą się z fragmentów baletów klasycznych z udziałem największych gwiazd zespołu, takich jak Alina Somowa, współpracująca z La Scalą solistka Teatru Maryjskiego w Petersburgu. W programie przewidziano między innymi popisy tancerzy do legendarnych choreografii: Michaiła Fokina, Agrippiny Waganowej, Rolanda Petit i Mariusa Petipa. Wizyty La Scali przyniosły publiczności ogromną satysfakcję obcowania z perfekcyjną sztuką tańca, a festiwalowi - zasłużone uznanie.

Aż trzykrotnie - na VI, XIX, XXII ŁSB - budząc podobne emocje, występował doskonały zespół Ballet National de Marseille. Balet założony w roku 1972 przez samego Petita - i przez 26 lat przez niego prowadzony - już na VI ŁSB (1981) zaprezentował jedną $\mathrm{z}$ najsłynniejszych choreografii swojego mistrza: Coppélię Léo Delibesa (z 1975 r.). Kompania Petita na łódzkim festiwalu zabłysnęła „[... ] najwyższym kunsztem inscenizacyjnym i wykonawczym”, a osiągnięta przez choreografa „nieskazitelna czystość stylistyczna” sytuowała widowiska „na najwyższym poziomie sztuki baletowej i teatralnej" 82 . W roku 1998 Petit opuścił grupę, a dyrekcję objęła Marie-Claude Pietragalla, która odmieniła kierunek twórczego rozwoju teatru. Jej nowatorski i syntetyczny styl choreograficzny łódzka publiczność mogła poznać w czasie XX $Ł S B$. Do Łodzi artystka przyjechała już jednak z własnym zespołem - Pietragalla Compagnie. Natomiast balet marsylski od roku 2004 prowadzi Belg Frédéric Flamand, który przyjechał z zespołem na XIX i XXII ŁSB (2007 i 2013 r.), prezentując tu zróżnicowane stylistycznie propozycje; wśród nich znalazły się klasyczne choreografie Balanchine’a - Apollon Musagète Strawińskiego i Jerome’a Robbinsa - In G Major Ravela ${ }^{83}$. Ostatnie występy marsylskiej kompanii ukazały spektakularną przemianę uprawianej tu sztuki inscenizacji widowiska tanecznego. W roku 2013 Flamand zaprezentował festiwalowej publiczności choreografię do dwóch dzieł: Orfeusza i Eurydyki (Christopha Willibalda Glucka w wersji Berlioza) oraz do interdyscyplinarnego widowiska - Moving target, stworzonego do fragmentów muzyki wielu twórców (m.in. Bacha, Arvo Pärta i Boyana Vodenitcharova). Przedstawienie stanowiło przykład integracji tańca ze sztukami plastycznymi, technikami audiowizualnymi i koncepcjami architektonicznymi. Dzieło zostało stworzone we współpracy z nowojorskimi architektami z eksperymentującej pracowni Diller+Scofidio. Spektakl ów był pionierską taneczno-architektoniczną wypowiedzią na temat poczucia rozpadu psychiki współczesnego człowieka, do czego fabularnej inspiracji dostarczyły nieocenzurowane dzienniki Niżyńskiego. W dziejach Spotkań

81 Zob. Stanisław Bromilski, XX wiek - złoty okres tańca, Program XXI ŁSB ..., s. 5.

82 Ewa Pankiewicz, Powrót tańca...

83 Zob.: Michał Lenarciński, XIX Łódzkie... ; Monika Wasilewska, Zakończyły się XIX Łódzkie Spotkania Baletowe, „Gazeta Wyborcza - Łódź” 2007, nr 131. 
Moving target znamionowało przekroczenie kolejnej artystycznej granicy: prezentację nowoczesnego widowiska, które z tańca czyni tylko jeden z elementów wypowiedzi artystycznej.

„Klasykę klasyki” zdawała się natomiast zapowiadać Giselle, przywieziona przez szwedzki Cullberg Ballet na XIV ŁSB (1997). Wielbiciele i znawcy tańca wiedzieli jednak doskonale, że w wersji Matsa Eka, choreografa zespołu, i w wykonaniu „Cullbergów”, trudno spodziewać się baletu zgodnego z akademicką konwencją. Awangardowa grupa, jedna z najlepszych na świecie, mistrzowska wśród zespołów reprezentujących technikę tańca modern, przyjeżdżała na ŁSB trzykrotnie, w latach 1997, 2001 i 2007. W dziedzinie tańca współczesnego - drugiego ze wspomnianych biegunów prezentacji festiwalowych - to najważniejszy spośród odwiedzających Łódź zespołów ${ }^{84}$. Kompania została stworzona w roku 1967 przez tancerkę i choreografkę Birgit Cullberg, m.in. twórczynię przełomowej i kanonicznej dla współczesnego tańca choreografii do Panny Julii wg dramatu Augusta Strindberga z muzyką Turego Rangströma (1950). Tę wspaniałą choreografię festiwalowa publiczność także miała okazję obejrzeć - w roku 1976, na V ŁSB - w wykonaniu Teatru Wielkiego w Warszawie, z Bożeną Kociołkowską w roli tytułowej. Po odejściu z Culberg Ballet jego założycielki, kierownictwo grupy objął Mats Ek, syn artystki - doskonały choreograf, reżyser teatralny, reformator tańca, tancerz - który prowadził grupę do roku 1993. W tym czasie Ek stworzył dla zespołu ponad 20 utworów, wśród nich sensacyjne wówczas wersje klasycznych baletów: Giselle (1982), Jeziora łabędziego (1987), Carmen (1992) czy Śpiącej królewny (1996). Już podczas pierwszej wizyty grupy na Biennale widzowie obejrzeli niezwykłą Giselle „Cullbergów”. Słynny romantyczny balet, z muzyką Adolphe’a Adama i z poetyckim librettem Théophile’a Gautiera napisanym wraz z Jules'em-Henrim Vernoyem de Saint-Georges'em, przedstawiony został w wersji zupełnie różnej od oryginału i w radykalnie zmienionej scenerii. Zamiast tradycyjnego „białego” II aktu (wykonywanego przez tancerki ubrane $\mathrm{w}$ romantyczne tiulowe tutu), czyli spodziewanego wyobrażenia królestwa willid (duchów dziewcząt zmarłych przed ślubem z powodu nieszczęśliwej miłości, które uwodzą nocą młodzieńców i porywają ich do morderczego wirowania w tańcu), Ek przedstawił obraz szpitala psychiatrycznego, do którego trafia tracąca zmysły bohaterka. Zaś nadzorująca Giselle Mirta, bardziej niż królową willid, przypominała siostrę Ratched, Wielką Oddziałową z Lotu nad kukułczym gniazdem - powieści Kena Keseya i filmu Miloša Formana. Prowokacyjne dzieło, znamionujące zamiłowanie Eka do teatralizacji i łączenia psychologicznej interpretacji fabuły $\mathrm{z}$ wyrafinowanym i przewrotnym poczuciem humoru, niestroniące

84 O twórczości Cullber Ballet zob. m.in.: Wojciech Klimczyk, Wizjonerzy..., s. $188-190$. 
od estetyki brzydoty i groteski, z wielkim sukcesem grane było przez szwedzki zespół ponad trzysta razy, w blisko 30 krajach. Także w Łodzi przyjęto je z ogromnym zainteresowaniem, a jeśli nawet nie wszystkim widzom przypadła do gustu niepokorna wersja Giselle, to zaproponowane na XIV ŁSB inne utwory: Solo for Two (Pärt/Ek); She Was Black (Henryk Mikołaj Górecki/Ek), Born at the Point of Impact (zespół Dead Can Dance/Jens Östberg) zyskały wielkie uznanie. Po czterech latach grupa powróciła na Biennale z kolejną buntowniczą inscenizacją Eka - Śpiąca królewna Czajkowskiego (XVI ŁSB). I znów tolerancja baletowych konserwatystów została wystawiona na próbę. W wersji szwedzkiego artysty Królewna Aurora jest narkomanką, a Wróżka Carabosse dealerką narkotyków. Zamiast końcowej apoteozy z unoszącą się nad baśniowymi postaciami Wróżką Bzu, widzowie zobaczyli wieloznaczną, dramatyczną scenę, w której Aurora wydaje na świat szarosrebrne wielkie jajo. Publiczność sama musiała zdecydować jak interpretować ów obraz. „Jedynym elementem łączącym to przedstawienie ze światem baśni jest taniec. Taniec kreuje świat, w którym wszystko się może zdarzyć. [... ] Jest precyzyjny i formalny, ale choreograf nie boi się sięgać po zwykłe gesty i włączać je w tkankę spektaklu. Wykorzystuje pęd i energię" 85 . Swoimi spektaklami Ek prezentował oszołomionym widzom prawdziwy triumf tańca. Przekonywał, iż zawarte w mitach i baśniach archetypowe prawdy stały się dziś kliszami i wymagają nowego odczytania, odniesienia ich do sytuacji egzystencjalnej współczesnego człowieka ${ }^{86}$. Jak mówił: „Musimy się odważyć być brzydcy, nieprzyjemni, staroświeccy, dziwaczni, wtedy dotrzemy do źródła naszej sztuki"87. Podobnie jak fabuła Śpiącej królewny daleka była od premierowej wersji libretta baletu-feerii (Iwana Wsiewołożskiego i Mariusa Petipy wg bajki Charlesa Perraulta), tak i choreografia Eka bardzo odbiegała od modelowych redakcji dzieła, choć artysta nigdy nie zrezygnował z wykorzystywania techniki tańca klasycznego. W trakcie ostatniej z dotychczasowych wizyt w Łodzi, w roku 2007 (XIX ŁSB), zespół pokazał trzy duże dzieła w ciągu dwóch wieczorów, w tym m.in. utwór Aluminium w choreografii Eka z muzyką Johna Adamsa, czyli taneczną opowieść o związku dwojga ludzi. Jak spostrzegła recenzująca spektakl Monika Wasilewska, w przedstawieniu: „Rysujące się między tancerzami relacje emanują czułością, by przejść po chwili w ostrą, surową wymianę. Walka przeplata

85 Edyta Hajduk, Zatańcz to..., s. 81.

86 Zob. Mats Ek, cytat z: Program XVI $E S B$, opr. i red. programu Dział Wydawnictw i Poligrafii Teatru Wielkiego w Łodzi, maj 2001, s. 24, http://archive.batsheva. co.il/files/attribute/1429701912m12DD.pdf (dostęp: 20.07.2016).

87 Mats Ek, Jadwiga Majewska, Aleksander Laskowski, Tancerze i aktorzy [wywiad z Maksem Ekiem], „Teatr” online 2013, nr 10, https://www.encyklopediateatru.pl/artykuly/170155/tancerze-i-aktorzy (dostęp: 4.10.2016). 
się z miłością, a każda codzienna sytuacja wypełnia się zmaganiem" ${ }^{88}$. Pragnienie doświadczania tak przejmujących obrazów sprawia, że publiczność zawsze szczelnie wypełnia ogromną salę Teatru Wielkiego w czasie występów Cullberg Ballet. I choć w latach 2003-2008 funkcję choreografa i dyrektora artystycznego zespołu sprawował Johan Inger, szwedzki tancerz i choreograf, który zmienił styl nowych widowisk „Cullbergów”, zbliżając je do formy współczesnego teatru tańca (Walking Mad Blanco), to rozpoznawalna poetyka twórczości Eka (dziś już ponad 70-letniego), patronuje zespołowi nadal, mimo że grupa współpracuje też z takimi artystami jak Jiří Kylián, Christopher Bruce, William Forsythe czy Ohad Naharin. Ten perfekcyjny zespół odwzajemnia uznanie, jakim od lat cieszy się na ŁSB i wysoko ceni festiwal, a artyści „[... ] uważają go za jeden z bardziej prestiżowych w Europie"89. Dla publiczności ich występy nieodmiennie stanowią entuzjastycznie witane wydarzenia. To właśnie „Cullbergom” łodzianie zawdzięczają wielkie wzruszenia i intensywną artystyczną edukację.

Baletem o nadzwyczajnej renomie, łączącym w swojej praktyce wykonawczej klasykę, neoklasykę i taniec współczesny, dwukrotnie goszczącym na ŁSB, był także Royal Ballet of Flanders (Królewski Balet Flandrii) z Antwerpii. Zespół założony w roku 1969 przez Jeanne Brabants - tancerkę i twórczynię około dwustu choreografii - w latach 80 . prowadzili świetni tancerze i zdolni choreografowie: Valery Panov ${ }^{90}$ oraz Robert Denvers ${ }^{91}$. W latach 2005-2012 grupe przejęła pod opiekę artystyczną Kathryn Bennetts, która rozwinęła i unowocześniła kreacje zespołu, pozyskując do współpracy swojego mistrza, czołowego wspólczesnego choreografa - Williama Forsythe'a. Pierwszy raz kompania wystąpiła w Łodzi na XIV festiwalu w roku 1997, czyli wówczas, gdy łodzianie oglądali też Giselle Eka. Zaprezentowano śmiały inscenizacyjnie wieczór baletowy, złożony $\mathrm{z}$ pięciu utworów przygotowanych przez czterech choreografów: Béjarta do muzyki Bacha; amerykańskiego tancerza, choreografa, pisarza i reżysera Christophera d'Amboise’a do utworów Leonarda Bernsteina; flamandzkiego choreografa Danny'ego Rosseela do muzyki Thomasa Oboe Lee oraz przybyłego z Argentyny potomka polskich Żydów - Mauricia Wainrota - do fragmentów oratorium

88 Monika Wasilewska, Relacje emanują czułością, „Gazeta Wyborcza - Łódź” 2007, nr 115, http://lodz.wyborcza.pl/lodz/1,35135,4139891.html (dostęp: 16.08.2016).

89 Stanisław Dyzbardis, Monika Wasilewska, Wierzę w site...

90 Były główny tancerz Baletu Teatru Maryjskiego w Petersburgu (wówczas jeszcze - do roku 1992 - Leningradzkiego Państwowego Akademickiego Teatru Opery i Baletu im. S.M. Kirowa), zob.: strona Ballet Panov Theatre, https://www.balletpanov.com/ en/valery-panov (dostęp: 20.08.2016).

91 Dziesięć lat tańczył w Ballet du XX-e siècle, http://dancedialogues.prattsils. org/items/show/124 (dostęp: 20.08.2016). 
Mesjasz Georga Friedricha Händla. Czternaście lat później, na XXI ŁSB w roku 2011, Bennetts przywiozła wielki zespół Royal Ballet of Flanders z arcydziełem Forsythe'a, rewolucyjnym spektaklem Artifact (muzyka: Bach, Eva Crossman-Hecht; choreografia, dekoracje, kostiumy i światło - Forsythe), liczącym już wówczas 27 lat $^{92}$. To czteroaktowe autotematyczne przedstawienie, „[...] w którym Forsythe reinterpretuje zasady istnienia tańca na scenie w stosunku do innych komponentów teatralnego doświadczenia, takich jak iluzja, narracja, ciągłość" 93 przemieniło w swoim czasie wyobrażenia o estetyce współczesnego tańca na całym świecie. Jak pisze Anastasia Nabokina, Forsythe: „Dokonując nieznacznych przemieszczeń w dobrze znanych układach tańca klasycznego, pokazuje, że trwałość i niezmienność schematów baletowych jest złudzeniem. [...] Język choreograficzny Forsythe’a nazywany jest poetyką znikania [ ...]. Ulotność, improwizacja jest jednym z narzędzi jego pracy" 94 . Tak znaczące przeistoczenie sposobu myślenia o tańcu, o funkcji i wizerunku ciała tancerza w ruchu, wymagało od publiczności ŁSB już nie tylko solidnej erudycji tanecznej, którą zdobywała wszak przez lata uczestniczenia $\mathrm{w}$ festiwalu, ale także rozbudzenia w sobie wrażliwości odbiorczej, czułej na zmysłowy język nowoczesnej sztuki. Pozostaje mieć nadzieję, że Royal Ballet of Flanders kolejny raz odwiedzi łódzkie Biennale i wraz ze swoim nowym choreografem i dyrektorem artystycznym - Sidi Larbi Cherkaoui 95 udowodni nieprzewidywalność współczesnych praktyk tanecznych.

Odwiedzających ŁSB znakomitych zespołów, eksperymentujących z nowymi technikami tańca współczesnego, było znacznie więcej. Rosnąca ranga festiwalu powodowała, że nie omijały go nawet najświetniejsze grupy; trudno je wszystkie wymienić. Ale tropiąc znamiona prestiżu i edukacyjne ścieżki Biennale, nie sposób tu pominąć obecności jeszcze trzech światowej marki zespołów: Nederlands Dans Theater, Batsheva Dance Company i Kibbutz Contemporary Dance Company, wszystkich o rewolucyjnym znaczeniu dla sztuki tańca.

Nederlands Dans Theater (NDT) powstał w Hadze w roku 1959, kiedy to część tancerzy odeszła z Het Nationale Ballet, aby intensywnie ćwiczyć technikę modern dance i rozwijać nowe formy ruchu scenicznego. Swój niepowtarzalny

92 Premiera odbyła się w Frankfurt Ballett w 1984 roku. Zob. też.: Program XXI $€ S B \ldots$

93 Joanna Bednarczyk, Wyobraźnia i zmysty - ECHA CZASU Polskiego Baletu Narodowego, TaniecPOLSKA.pl 2012, http://www.taniecpolska.pl/krytyka/164 (dostęp: 25.08.2016).

94 Anastasia Nabokina, Głos z oddali, „Teatr” 2013, nr 1, http://www.e-teatr.pl/pl/ artykuly/155502,druk.html (dostęp: 18.08.2016).

95 Artysta z grupą argentyńskich tancerzy i muzyków zaprezentował na XXIII ŁSB (2013) spektakl Milonga. 
styl NDT osiągnął jednak dopiero pod dyrekcją artystyczną czeskiego wirtuoza współczesnej choreografii - Jiřiego Kyliána, który w latach 1975-1999 przygotował tu ponad 50 swoich dzieł. Stworzona przez Kyliána grupa Junior (później: Nederlands Dans Theater II) przyjechała do Łodzi już w roku 1983, prezentując wówczas na VII ŁSB wyborny program: Zatopiona katedrę (Claude Debussy/Kylián), Pieśń bez stów (Felix Mendelssohn-Bartholdy), w choreografii legendarnego mistrza haskiego zespołu, autora ponad 120 dzieł - Hansa van Manena ${ }^{96}$, oraz Dancing Day (Gustav Holst), utwór Christophera Bruce'a, uznawanego za ostatniego $\mathrm{z}$ wielkich choreografów wykształconych przez Marię Rambert. Na jubileuszowych XX Spotkaniach (2009) NDT II pokazał wybitne prace Kyliána: 27'52 (Dirk Haubrich) i Gods and Dogs (Beethoven, Haubrich) oraz Subject to Change w choreografii duetu Sol León \& Paul Lightfoot, z muzyką Franza Schuberta (Śmierć i dziewczyna). Wszystkie trzy utwory grane były w Polsce po raz pierwszy i prawdziwie zelektryzowały krytykę. Dzieła Kyliána, łączące klasyczną technikę z praktyką i stylem tańca uprawianego np. w kulturach pozaeuropejskich, uwodzą pięknem scenicznego obrazu. Obecność na Spotkaniach artystów z Nederlands Dans Theater wskazuje na rangę wydarzenia, jakim stał się łódzki festiwal - to z NDT wywodzi się grono najwyżej cenionych współczesnych choreografów. Obok Kyliána wyszli stąd także: Forsythe, Duato, Naharin, Lightfoot. Dzieła wszystkich z nich, a tym samym reprezentatywne dla współczesnej sztuki strategie i praktyki choreograficzne, można było poznać dzięki istnieniu Biennale.

Kunszt artystyczny Naharina podziwiano podczas trzykrotnych wizyt na festiwalu kompanii tańca nowoczesnego - Batsheva Dance Company (BDC) z Izraela. Grupa powstała w roku 1964 z inicjatywy dziedziczki bankierskiej fortuny - Bethsabée de Rothschild (imię Batsheva, od którego pochodzi nazwa zespołu, założycielka przyjęła po przeprowadzce do Izraela ${ }^{97}$ ). Jest to najstarsza kompania tańca nowoczesnego w Izraelu; jej pierwszą nauczycielką i opiekunką była sama Martha Graham ${ }^{98}$. Na Łódzkich Spotkaniach Baletowych zespół wystąpił w latach: 1989 (X ŁSB), 1991 (XI ŁSB) oraz 2001 (XVI ŁSB). W czasie jubileuszowych X Spotkań przedstawiono cztery wyjątkowe w dotychczasowych dziejach $E S B$ utwory. Były to słynne choreografie najbardziej cenionych współczesnych artystów tańca: dwie prace Daniela Ezralova - SVSPLKT do

96 W 1999 roku inne głośne prace van Manena (Trois Gnossiennes Erika Satie i Twilight Johna Cage'a) oraz legendarną choreografię Twyli Tharp - In the Upper Room do muzyki Philipa Glassa pokazał na ŁSB Dutch National Ballet.

97 Zob. strona internetowa Batsheva Dance Company, https://batsheva.co.il/en/ about?open=Batsheva-De-Rothschild (dostęp: 15.07.2016).

98 Ibidem. 
kompozycji Toma Waitsa i muzyki indonezyjskiej oraz Psycho killer do utworów zespołu Talking Heads, a także propozycja Naharina do Tabula Rasa Pärta. Zgodnie z programem ${ }^{99}$, planowano także prezentację choreografii do muzyki Philipa Glassa (Eight Heads), lecz ostatecznie zamiast niej włączono do składu wieczoru choreografię Roberta Northa do efektownego Entre dos Aguas (muzyka: Paco de Lucia i José Alcaraz Torregrosa). I właśnie ten ostatni utwór, oparty na sztuce flamenco, cieszył się największym uznaniem odbiorców ${ }^{100}$. Zespół Batsheva Dance Company przyjechał na $€ S B$ tuż po tym, jak broniąc prawa do własnego sposobu ekspresji artystycznej i przeciwstawiając się cenzurze religijnej, odmówił wzięcia udziału w oficjalnych obchodach 50. rocznicy Dnia Niepodległości w Izraelu. Ta odmowa wywołała ogromną falę poparcia dla postawy artystów i stała się manifestacją potrzeby wolności w sztuce. Ale znaczenie wizyty izraelskiego zespołu na ŁSB polegało nie tyle na wzmacnianiu poczucia niezależności, ile na pogłębieniu świadomość współczesnych technik tańca. Już wówczas widzowie festiwalu mogli doświadczyć początków istnienia innowacyjnego języka ruchu, wprowadzanego przez Naharina od roku 1986 (to także rok premiery Tabula Rasa) do praktyki zespołu BDC. Ów język ruchu, zwany GAGA, artysta rozwijał w latach 1990-2003, kiedy to pełnił funkcję dyrektora artystycznego zespołu ${ }^{101}$. GAGA: „To zarazem filozofia pracy z ciałem, kompleksowy trening dla tancerzy i forma aktywności fizycznej dostępna dla ludzi niezwiązanych profesjonalnie z ruchem $[\ldots]]^{\prime 102}$, to improwizowany sposób budzenia świadomości własnego ciała. Po swojej pierwszej wizycie w Łodzi zespół zaprosił troje choreografów polskich: Ewę Wycichowską, Emila Wesołowskiego i Krzysztofa Pastora do przygotowania w Izraelu wieczoru baletowego do muzyki polskich kompozytorów, co uwidacznia promocyjną funkcję ŁSB. Dwa lata później Izraelczycy przywieźli na Biennale spektakl Kyr do muzyki zespołu The Tractor's Revenge w choreografii Naharina (od roku 1990 dyrektora artystycznego teatru). Artysta powrócil na Spotkania z zespołem BDC dziesięć lat później, w roku 2001, i pokazał wówczas głośne widowisko z 1993 roku - Anaphaza (muzyka: Aaron Copland, Guem, Pärt, Avi Belleli, Rolf

99 Zob. Program: 20.05-10.06, X Łódzkie Spotkania Baletowe'89... Programy ŁSB, w których brał udział izraelski zespół Batsheva Dance Company, dostępne są $\mathrm{w}$ wersji elektronicznej $\mathrm{w}$ archiwum Bat-Sheva, http://archive.batsheva.co.il/files/ attribute/1429549196p96UK.pdf (dostęp: 15.08.2016).

100 Zob. Jerzy Kwieciński, X Łódzkie Spotkania Baletowe. Z zamorskich krajów, „Odgłosy. Tygodnik Społeczno-Kulturalny" 1989, nr 26, s. 9.

101 Zob.: strona Batsheva Dance Company, https://batsheva.co.il/en/gaga (dostęp: 10.10.2016).

102 Zob.: Agnieszka Sterczyńska, „Connect to pleasure”, czyli GaGa Ohada Naharina, wortal: http://www.taniecpolska.pl/krytyka/274 (dostęp: 15.10.2016). 
Wallin, Dan Markov, Ohad Naharin), które było jedną z wypowiedzi inicjujących jego filozofię ruchu. Fascynujący charakter tańca opracowanego przez Naharina oddaje ciąg epitetów pojawiający się w zwiastunie filmu Mr. Gaga Tomera Heymanna (2015): „mocny, ostry, swobodny, szlachetny, lagodny, czysty, kruchy, oszczędny, zmysłowy, szorstki, szybki, delikatny, miękki, zwierzęcy"103.

Ogromne uznanie niezmiennie budzi w Łodzi także inny izraelski zespół tańca nowoczesnego - Kibbutz Contemporary Dance Company (KCDC). Pierwszy raz kompania odwiedziła $€ S B$ w roku 1997, a więc równolegle z pierwszą wizytą na festiwalu „Cullbergów”. Kolejny raz Izraelczycy pojawili się tu w roku 2003 i wówczas ich występ miał podwójne znaczenie: zamykał XVII Biennale i był wstępem do Festiwalu Dialogu Czterech Kultur. Po raz trzeci zaś Kibbutz zaprezentował się na wyjątkowej edycji Biennale - jubileuszowych XX Spotkaniach (2009). Zespół stworzyła Yehudit Arnon, która po tragicznych wojennych przeżyciach w nazistowskich obozach zagłady (w Auschwitz, w Birkenau i w obozie na Morawach) osiedliła się w Zachodniej Galilei w Izraelu, w Kibbutz Ga’aton. Tam też, od lat 60. XX wieku, zajęła się kształceniem tancerzy, a w roku 1970 zainicjowała w kibucu działalność KCDC ${ }^{104}$. Kierowała zespołem artystycznie do roku 1996, po czym przekazała tę funkcję tancerzowi i choreografowi urodzonemu w Kibbutz Ga'aton - Ramiemu Be’erowi, który prowadzi zespół do dziś. To jego inscenizacyjnie minimalistyczny styl choreografii, dbałość o wirtuozowskie operowanie światłem i - przede wszystkim - niezwykle dynamiczny, ekstatyczny rodzaj tańca (z elementami tańca fizycznego) stały się znakiem rozpoznawczym KCDC. Grupa zyskała sławę jednego z najlepszych teatrów tańca na świecie. W Łodzi Be'er pokazał swoje znane choreografie, takie jak: Aide Memorie (1997) - wstrząsającą refleksję nad Holokaustem i przemocą we współczesnym świecie, Ekodoom czy Upon Reaching the Sun (m.in. do muzyki Massive Attack).

W tym krótkim przeglądzie obecnych na $\mathrm{ESB}$ rewolucyjnych zespołów poszukujących idiomu współczesnego tańca zabrakło miejsca dla wielu grup. Osobną uwagę należałoby poświęcić zespołom amerykańskim, słynącym z wyrafinowanej poetyki ruchu: Lar Lubovitch Dance Company (VI ŁSB, 1981), ISO Dance Theatre, pod dyrekcją i z udziałem samego Daniela Ezralova (XII ŁSB, 1993), Complexions Contemporary Ballet (XIX ŁSB, 2007 - choreografie Dwighta Rhodena) czy grupa dziedzicząca idee tańca Alvina Aileya - Ailey II (XXII, 2013). Należałoby także podkreślić np. unikalność i niezwykłe piękno

103 Mr. Gaga, reż. Tomer Heymann, 2015, https://www.youtube.com/ watch?v=4gfQkggxlik (dostęp: 12.09.2016).

104 Zob. np.: Encyclopedia: Yehudit Arnon 1926-2016, https://jwa.org/encyclopedia/article/arnon-yehudit (dostęp: 10.12.2016); strona zespołu: https://www.kcdc. co.il/en/ (dostęp: 10.12.2016). 
synkretycznych propozycji artystycznych Akrama Khana (Akram Khan Company, XXI ŁSB, 2011) czy kreatywnych, badających nowe aspekty ruchu dzieł Russella Maliphanta (XXII ŁSB, 2013). Niestety, trzeba poprzestać tu jedynie na zasygnalizowaniu ich obecności.

Na Łódzkie Spotkania Baletowe do Teatru Wielkiego przyjeżdżały oczywiście nie tylko grupy zagraniczne, ale także wszystkie ważniejsze krajowe zespoły baletowe, które przedstawiały tu swoje najlepsze widowiska. Przez dłuższy czas jednak, co zgodnie podkreślali recenzenci, większość polskich produkcji nie nadążała za szybkim rozwojem współczesnego tańca na Zachodzie. To właśnie udział w ŁSB stwarzał rodzimym teatrom nadzwyczajną okazję doświadczania nowego języka ruchu i metod pracy nad nim, a w rezultacie - modernizowania swojej praktyki wykonawczej. Obok wiodących krajowych scen operowo-baletowych - warszawskiej, łódzkiej, poznańskiej, gdańskiej i wrocławskiej - istniał jednak polski zespół zdolny z powodzeniem podjąć rywalizację z gwiazdami światowego baletu, które odwiedzały Biennale: Polski Teatr Tańca - Balet Poznański. Przypomnijmy, że grupa po raz pierwszy wystąpiła na IV Spotkaniach w 1974 roku, czyli rok po jej stworzeniu przez Conrada Drzewieckiego. Do roku 2013 zespół przyjechał na $Ł S B$ jeszcze 14 razy, w tym pięciokrotnie pod dyrekcją Drzewieckiego, kiedy to spektakle poznańskich artystów reprezentowały formułę teatru tańca ich mistrza. W roku 1988 dyrektorem naczelnym i artystycznym Teatru została Ewa Wycichowska (sprawowała tę funkcję do sierpnia 2016 r.). Artystka, jako wybitnie i wszechstronnie utalentowana tancerka, uwielbiana w Łodzi wieloletnia solistka i primabalerina Teatru Wielkiego ${ }^{105}$, z historią Spotkań związana była w sposób wyjątkowy. Jej debiut sceniczny (Teatr Wielki w Łodzi, Jezioro łabędzie w choreografii Witolda Borkowskiego) przypadł na rok powstania Biennale, po czym przez 45 lat brała udział prawie we wszystkich edycjach festiwalu ${ }^{106}$. Już

105 Młodą dyplomantkę Ewę Wycichowską zaprosił w 1968 roku do tworzonego w Teatrze Wielkim zespołu baletowego Witold Borkowski i artystka spędziła tu, jako tancerka i choreografka, 20 lat. Tańczyła w 36 przedstawieniach, w repertuarze klasycznym i współczesnym, najczęściej jako solistka, bardzo często w tytułowych/głównych rolach najsłynniejszych baletów (np. jako: Julia w Romeo i Julii, Gajane, Królewna Śnieżka, Liza w Córce źle strzeżonej, Maria w Fontannie Bachczysaraju, Małgorzata w Faust story, Szecherezada, Ognisty ptak, Giselle, Coppélia czy Medea). Na 25-lecie pracy artystycznej Wycichowskiej Teatr Wielki w Łodzi zorganizował uroczysty wieczór baletowy, w którym Jubilatka tańczyła jedną ze swoich legendarnych ról: Carmen w choreografii Jerzego Makarowskiego, do muzyki Bizeta, Rodiona Szczedrina i Heitora Villa-Lobosa (16 II 1994). Zob. np. Cyfrowe Muzeum Teatru Wielkiego w Łodzi, http://www.cyfrowemuzeum.operalodz.com/ (dostęp: 15.08.2021).

106 Zob. wypowiedź Ewy Wycichowskiej, Program teatralny: SPOTKANIA $w$ dwóch niespetnionych AKTACH, Teatr Wielki w Łodzi, red. programu Iwona Marchew- 
w czasie drugich Spotkań w roku 1970 tańczyła jedną ze swoich legendarnych ról - Królewnę Śnieżkę, w pokazanym przez gospodarzy balecie Królewna Śnieżka i siedmiu krasnoludków (Bogdan Pawłowski/Borkowski, premiera: 14 III 1970; przedstawienie nadal grane jest $w$ tej wersji $w$ wielu teatrach). Na kolejnych festiwalach Wycichowska stworzyła szereg niezapomnianych kreacji tanecznych, by przypomnieć tylko wspomniane już: Dziewczynę w Zielonym stole Joossa czy Gajane w inscenizacji Ejfmana.

Zasilając ansambl Teatru Wielkiego, a potem prowadząc poznański zespól, Wycichowska z sukcesami reprezentowała polską sztukę tańca. W dziedzinie choreografii, inscenizacji i reżyserii stawała do konkurencji z międzynarodowym gronem artystów. Pierwszą pracą choreograficzną Ewy Wycichowskiej był spektakl Gtos kobiecy ( $z$ nieznanej poetki), balet w jednym akcie do cyklu wierszy Rafała Wojaczka z muzyką Krzysztofa Knittla, przygotowany z zespołem Teatru Wielkiego w Łodzi w roku 1980. Już rok później odbyły się tu premiery Serenady Karłowicza, Koncertu f-moll Chopina i Stabat Mater Karola Szymanowskiego, do których Wycichowska przygotowywała libretta, choreografie i inscenizacje. Spośród innych tódzkich premier trzeba przynajmniej wymienić, wielokrotnie oklaskiwany w Polsce i w Europie, rock-balet Faust goes rock do muzyki zespołu The Shade (1986)107, w którym artystka tańczyła też partię Mefisty, oraz Święto wiosny (1989 i 1993). Do roku 2015 Ewa Wycichowska przedstawila polskiej i zagranicznej publiczności ponad 70 swoich przedstawień ${ }^{108}$. We wczesnych latach 80 . rozpoczęła też wieloletnią współpracę z czołowymi polskimi reżyserami teatralnymi, operowymi i filmowymi ${ }^{109}$. W sztuce choreograficzno-inscenizacyjnej Wycichowskiej ruch i gest, muzyka, plastyka i dramaturgia stanowią przenikające się formy ekspresji, wspólnie tworząc wyraziste, choć plynne gatunkowo widowiska. ŁSB sięgały po twórczość Ewy Wycichowskiej wielokrotnie. Teatr Wielki, jako gospodarz, pod dyrekcją Sławomira Pietrasa, w czasie VIII Biennale (1985) przedstawił Wieczór Baletowy, który stanowił autorski program artystki. Składały się na niego: choreomonodram Cień II do kompozycji Alea Bronisława Kazimierza Przybylskiego, Pax et bonum do oratorium Łuciuka Św. Franciszek $z$ Asyżu

ka, Maria Rżanek, Łódź 2011, s. 5.

107 Światowa prapremiera utworu odbyła się w Hanowerze 8 X 1986 roku z udziatem zespołu Shade.

108 Zob.: Hasło 'Ewa Wycichowska' na stronie Instytutu Muzyki i Tańca, http:// www.taniecpolska.pl/ludzie/201 (dostęp: 20.09.2016).

109 Powstały wówczas na łódzkiej scenie nowatorskie premiery: Karłowicz - Interpretacje w inscenizacji Adama Hanuszkiewicza (1983) oraz Republika - Rzecz Publiczna, spektakl oparty na Wyludniaczu Samuela Becketta oraz na muzyce Grzegorza Ciechowskiego i zespołu Republika. 
oraz Miriam (Przybylski), na motywach opowiadania Trumana Capotea. Wszystkie utwory z librettem, w choreografii i w inscenizacji Wycichowskiej, a także z jej udziałem jako solistki ${ }^{110}$. W kolejnych latach, już kierując Polskim Teatrem Tańca - Baletem Poznańskim, który prowadziła przez 27 sezonów, Wycichowska przyjeżdżała z zespołem na Biennale dziesięć razy - najczęściej spośród wszystkich zapraszanych tu teatrów ${ }^{111}$. PTT prezentował na Spotkaniach swoje najlepsze premiery, $\mathrm{w}$ większości będące realizacją koncepcji inscenizacyjno-choreograficznych Wycichowskiej, ale także przygotowywane przez pozyskiwanych do współpracy artystów. W pierwszym okresie były to głównie wieloczęściowe duże widowiska taneczne, takie jak: Niżyńskiemu - une soirée (X ŁSB, 1989)112; Mozart a piacere (XI ŁSB,1991) ${ }^{113}$; na XII ŁSB, w roku 1993, poznaniacy przywieźli aż dwa takie spektakle: Hommage a Ginastera ${ }^{114}$ oraz Sekundy samotności (zawierające m.in. utwór przygotowany do poezji Stanisława Barańczaka - Album z tego świata, z muzyką Krzesimira Dębskiego ${ }^{115}$ ). Na XIII ŁSB zespół przedstawił Pót dnia Pólnocy w choreografii samego Matsa Eka (do utworu szwedzkiej grupy muzycznej J.P Nyströms), a także Już się zmierzcha (Góreckiego/ Wycichowskiej) oraz Fantazję na Harnasia (Kilara, Artura Malawskiego/ Wycichowskiej). W czasie rekordowego XI Biennale, PTT zaproponował dwa wieczory baletowe; obok spektaklu Mozartowskiego, słynny dramat mimiczny Bolesława Leśmiana Skrzypek Opętany. Dzieło poety zostało choreograficznie i scenicznie zinterpretowane przez Wycichowską (tańczyła także wspaniale rolę Chryzy), muzycznie

110 Program teatralny: VIII Łódzkie Spotkania Baletowe'85, Teatr Wielki w Łodzi, red. Iwona Marchewka, http://www.e-teatr.pl/pl/programy/2013_12/55299/wieczor_baletowy_teatr_wielki_lodz_1985.pdf (dostęp: 20.09.2016).

111 W latach1989-2013 na: X, XI, XII, XIII, XIV, XV, XVI, XVII, XX, XXI ŁSB.

112 Na spektakl składały się utwory: Samotność fauna Norbert Mateusz Kuźnik/ Wycichowska, Arlekin Robert Schumann/ Wycichowska, Duch róży Karol Maria Weber/ Wacław Gaworczyk, S'amor non è... Jerzy Satanowski/ Gustaw Klauzner, Pietruszka Strawiński/ Andrzej Glegolski, zob. Program teatralny: X£SB, http://archive.batsheva. co.il/files/attribute/1429549196p96UK.pdf (dostęp: 15.08.2016).

113 [W skład wchodziły: Mozartiana Czajkowski/ Emil Wesołowski, Symfonia koncertująca Es-dur na skrzypce i altówkę Mozart/ Wycichowska, Msza Koronacyjna Mozart/ Waldemar Wołk-Karaczewski, zob. Archiwum cyfrowe TW, http://www.cyfrowemuzeum.operalodz.com/category/lsb/xi-lodzkie-spotkania-baletowe/?lang=pl (dostęp: 25.05.2018) - przyp. red.]

114 [Przedstawienie złożone z: Vivre Szymanowskiego/ Barbary Gołaskiej oraz utworów Misterium słońca, Misterium ziemi Alberto Ginastery/Wycichowskiej zrealizowane zostało na zamówienie festiwalu Dresdner Musikfestspiele, ibidem - przyp. red.]

115 Wieloczęściowy balet pt. Sekundy samotności w roku 1992 zdobył Fringe Firsts Special Award na festiwalu w Edynburgu. 
przez Macieja Małeckiego, a plastycznie przez Ryszarda Kaję, autora scenografii i kostiumów do wielu przedstawień PTT. „To dziwne, halucynacyjnie piękne przedstawienie" 116 zyskało uznanie zagranicznych zespołów prezentujących tej wiosny na $€ S B$ wiele wyśmienitych spektakli. Wielka różnorodność propozycji tanecznych i duża grupa choreografów współpracujących z PTT (byli wśród nich m.in.: Cullberg, Ek, Naharin czy Karine Saporta) wynikała z polityki repertuarowej i kształceniowej artystki/dyrektorki, która pragnęła zapewnić swoim tancerzom jak najszersze doświadczenia twórcze. W efekcie zespół osiągnął wysokie umiejętności techniczne i wielką wrażliwość na różne języki współczesnego tańca, a jego tancerki i tancerze byli zdolni do podjęcia zarówno improwizacji, jak i samodzielnej twórczości choreograficznej. Grupa stała się jedną z bardzo pożądanych kompanii, nie tylko na łódzkich Spotkaniach, lecz na całym europejskim rynku baletowym, do czego Biennale także się przyczyniło ${ }^{117}$. Publiczność ŁSB, z uwagą i entuzjazmem obserwująca przez wiele lat rozwój artystyczny poznańskiego Teatru, mogła zauważyć jego odchodzenie od form teatru baletowego ku teatrowi tańca. Cechy tego gatunku: warsztatowa, stylistyczna i gatunkowa transgresyjność, ujęcie tańca - jak pisze Dobrochna Ratajczakowa - w „cudzysłów teatralnego efektu" 118 i w znacznym stopniu oparcie procesu tworzenia na kreatywnej improwizacji tancerzy, stało się szczególnie wyraźne w spektaklach PTT pokazywanych na Biennale w XXI wieku. Ale ewolucja teatru Ewy Wycichowskiej ku tej formie sztuki widoczna była już od łódzkiej Miriam oraz Faust goes rock poprzez prezentowane na Spotkaniach: Niebezpieczne związki i Daine (XIV ŁSB, 1997, Bach, Erik Satie oraz Tadeusz Szeligowski, Zbigniew Łowży1); +- skończoność (XV ŁSB, 1999, Michael Nyman, Luc Ferrari, spektakl ze scenografią Małgorzaty Szczęśniak); Tango z Lady M. (XVI ŁSB, 2001, Leszek Możdżer, Astor Piazzolla); Carpe Diem (XX ŁSB, 2009, Zbigniew Górny, Marcin Górny), aż po - przygotowane na specjalne zaproszenie XXI ŁSB, we współpracy z Teatrem Wielkim w Łodzi i z gronem lódzkich i poznańskich artystów seniorów - Spotkania $w$ dwóch niespetnionych aktach (XXI ŁSB, 2011, Paulina Załubska, Knittel). Biennale pozwoliło odbiorcom dostrzec i zdefiniować kierunek rozwoju

116 Małgorzata Musierowicz, Z Poznania. Będzie wspaniale, „Goniec Teatralny” (3 czerwca 1991), s. 5.

117 Zob. Uwodzenie widza - z Ewa Wycichowska i Jagoda Ignaczak rozmawia Anna Koczorowska, wortal: taniecPOLSKA.pl, 2016, http://www.taniecpolska.pl/krytyka/380 (dostęp: 20.09.2016).

118 Za: Dobrochna Ratajczakowa, Polski Teatr Tańca - Balet Poznański, [w:] eadem, $W$ krysztale $i w$ płomieniu. Studia $i$ szkice o dramacie i teatrze, t. 2, wybór i oprac. Barbara Koncewicz, Wydawnictwo Uniwersytetu Wrocławskiego, Wrocław 2006, s. 717. 
Polskiego Teatru Tańca - Baletu Poznańskiego i umożliwiło niezwykle intensywne uczestnictwo w twórczości Ewy Wycichowskiej i jej zespołu.

Reprezentacja przemian światowej sztuki tańca, konfrontacja i wymiana doświadczeń między najwybitniejszymi choreografkami i choreografami to niezwykle ważne cechy Łódzkich Spotkań Baletowych, niemniej festiwalowa publiczność zawsze najgoręcej oklaskiwała doskonałych tancerzy i tancerki. A podziwiać można było na Spotkaniach prawdziwe gwiazdy sztuki tańca, zarówno tancerzy klasycznych, zachwycających znawców sztuki tanecznej w perfekcyjnych grand jeté czy tour en l'air, jak i porywających dynamiką i zmysłowością ruchu mistrzów tańca współczesnego. Przypomnijmy: już na I ŁSB zachwycały swym kunsztem Alicja Boniuszko, Barbara Bittnerowna i Krystyna Mazurówna. Przez wszystkie festiwalowe lata przyjeżdżali na Spotkania, podnosząc poziom doświadczeń i oczekiwań łódzkiej publiczności, tak znakomici tancerze/tancerki jak: Alicia Alonso, Christina Hoyos, Tania Bari, Maina Gielgud, Christopher Bruce, Jorge Donn, Paolo Bortoluzzi, Daniel Ezralov, Russel Maliphan i wielu, wielu innych. Byli wśród nich także legendarni mistrzowie i mistrzynie, jedni z najwybitniejszych tancerzy/tancerek XX wieku: Sylvie Guillem, Ana Laguna i Michaił Barysznikow. Występy tych arcytancerzy przypadły na trzy bliskie sobie i wyborne edycje festiwalu: jubileuszowe XX (2009) - Baryshnikov Arts Center; XXI (2011) - Sylvie Guillem, Russell Maliphant i XXIII (2015) - inauguracja pożegnalnego tournée Sylvie Guillem.

Tę eksplozję święta tańca otworzył spektakl Three Solos and a Duet wykonany przez Barysznikowa z hiszpańsko-szwedzką doskonałą tancerką Aną Laguną. Artystka, tańcząca w latach 70. i 80. XX wieku w Culbberg Ballet i NDT, stworzyła swój unikalny dynamiczny styl tańca w choreografiach najświetniejszych współczesnych twórców, w tym przede wszystkim Matsa Eka, prywatnie swojego męża i artystycznego partnera. Barysznikow to oczywiście olśniewający mistrz, zarówno tańca klasycznego, jak i współczesnego, którym zajął się od końca lat 70. XX wieku, po uzyskaniu azylu w USA. Tańczył w American Ballet Theatre (ABT) oraz w New York City Ballet (NYCB), wspólpracując z Balanchinem, Graham, Twylą Tharp. Od początku lat 90. artysta podejmuje własne inicjatywy dotyczące tańca współczesnego; powołał we współpracy z Markiem Morrisem zespół White Oak Dance Project (WODP), wprowadzając do jego repertuaru legendarne choreografie: Mercego Cunninghama, Paula Taylora, Marthy Graham, Jerome’a Robbinsa czy Joségo Limóna. Grupa przyjechała do Polski w 2001 roku i wszystkie jej ówczesne występy - w Chorzowie, w Krakowie i w Warszawie - przebiegały $\mathrm{w}$ atmosferze szturmowania sal teatralnych przez rozentuzjazmowanych wielbicieli baletu. W roku 2001 artysta otworzył w Nowym Jorku interdyscyplinarną instytucję - Baryshnikov Arts Center, promującą sztukę eksperymentalną. I właśnie w ramach działalności tej sceny przyjechał wraz z Aną 
Laguną na Spotkania w roku 2009. Było to jedyne przedstawienie dane w Polsce w czasie europejskiego tournée tancerzy. Spektakl obejmował dwa solowe popisy Barysznikowa, w tym najnowszą, zaledwie dwutygodniową premierę utworu Valse-Fantasie Michaiła Glinki w choreografii wieloletniego dyrektora artystycznego Baletu Bolszoj, wówczas już związanego z ABT - Aleksieja Ratmańskiego (prapremiera odbyła się w Rydze, rodzinnym mieście tancerza, 2 V 2009). Żartowano, że ostatnim rosyjskim choreografem współpracującym z Barysznikowem, przed Ratmańskim, był Balanchine... ${ }^{119}$ Drugie solo artysty stanowił utwór Years later (Benjamin Millepied/Glass, Satie, Akira Rabelais), widowisko zawierające projekcję filmu rejestrującego występ młodego Barysznikowa (z 1968 r., czyli roku inauguracji $Ł S B)$, z którym dojrzały tancerz prowadzi pełen napięcia taneczny dialog. Jak pisała recenzująca łódzki spektakl Monika Wasilewska: „Jeden artysta zostaje tu rozszczepiony na dwie odrębne postacie; taneczną ikonę o niewyobrażalnej dyscyplinie ciała i realnego człowieka, któremu to samo ciało - lecz tak bardzo zmienione upływem czasu - wyznaczyło nieprzekraczalne bariery"120. Spektakl obejmował też dwa słynne duety w choreografii Matsa Eka - Solo for Two do muzyki Pärta oraz, stworzony specjalnie dla ansamblu Barysznikow - Laguna, Place do muzyki szwedzkiej grupy muzycznej Fläskkvartetten (2007 r.). Taniec Barysznikowa, jednego z zaledwie kilku (obok Niżyńskiego i Nurejewa) najświetniejszych dwudziestowiecznych danseur noble, pozwalał doświadczyć jednocześnie najwyższej perfekcji klasycznej techniki baletowej oraz witalności i ekspresji tańca współczesnego. W duecie z Aną Laguną siła wyrazu „ciała tańczącego" (corps dansant) ${ }^{121}$ obojga wirtuozów czyniła ich taneczne performanse dramatycznym obrazem relacji dwojga uwikłanych w siebie ludzi.

Już kolejne, wielokrotnie przywoływane tu XXI Biennale z 2011 roku, przyniosło spotkanie ze sztuką tańca jeszcze jednej legendy współczesnego baletu - francuskiej arcybaleriny Sylvie Guillem. Jedna z najwybitniejszych tancerek $\mathrm{XX}$ wieku, obdarzona wspaniałymi warunkami i dysponująca perfekcyjną techniką, wykonywała w czasie swojej kariery choreografie takich mistrzów jak Ashton, Béjart, Ek, Forsythe, Kahn, Jerome Robins, John Neumeier czy Kenneth MacMillan. Primabalerina Opery Paryskiej i Principal Guest Artist londyńskiego The

119 Zob.: Claudia La Rocco, He Has a Pass to Dance as Long as He Wants, „The New York Times” (5 May 2009), https://www.nytimes.com/2009/05/17/arts/ dance/17laro.html (dostęp: 16.08.2016).

120 Monika Wasilewska, Konfrontacja z legenda, „Gazeta Wyborcza - Łódź” 2009, nr 120 .

121 Por. Tom: Ciało tańczące, „Kultura Współczesna” 2011, nr 3(69); Joanna Szymajda, Tendencje estetyczne we wspótczesnym tańcu francuskim po 1990 roku, Łódź 2005, passim. 
Royal Ballet, tańcząca na najważniejszych scenach świata, po raz pierwszy pojawiła się w Polsce właśnie na Spotkaniach. Jak mówiła o wizycie w Łodzi: „Był to dla mnie pierwszy pobyt $\mathrm{w}$ Polsce i jestem pod urokiem tamtejszego [tzn. łódzkiego - M.K, I.J-L.] cmentarza żydowskiego. To miejsce magiczne"122. Przyjechała z Russellem Maliphantem, który stworzył choreografię do przedstawionego na festiwalu słynnego widowiska PUSH, a także partnerował artystce w tańcu. Na spektakl składały się cztery utwory. Otworzyło wieczór Solo (przygotowane specjalnie przez Maliphanta dla Guillem w 2005 roku), w którym artystka prezentowała swą niezrównaną technikę, nadzwyczajną ekspresję i elastyczność ciała w hiszpańskiej muzyce gitarowej Carlosa Montoyi. W drugim fragmencie - Shift z 1996 roku do muzyki Shirley Thompson - tańczył sam choreograf (i świetny tancerz), podejmujący w medytacyjnym, inspirowanym jogą tańcu dialog ze swoimi cieniami, w wykreowanej światłem wirtualnej przestrzeni. Reżyseria światła opracowana została przez prawdziwego mistrza tej sztuki - Michaela Hullsa. Kolejna część to olśniewające Two do muzyki Andy'ego Cowtona (1997 r.), w którym ujęte $\mathrm{w}$ zmienny krąg światła ciało Guillem powtarza z narastającą intensywnością spiralne sekwencje ruchu, aż po ekscytujący finał, przywodzący na myśl wirowanie derwiszów. Światło wydobywa i tłumi kontury sylwetki tancerki, niewiarygodnie precyzyjny ruch jej długich nóg i smukłych ramion, wygięte łuki stóp, zarys napiętych mięśni. I wreszcie tytułowe PUSH (2005 r., muzyka Cowton), śmiało eksplorujący przestrzeń duet Guillem i Maliphanta, wprowadzających swoje ciała $\mathrm{w}$ wyrazisty, skupiony na wzajemnym kontakcie ruch, kontrastowany z zatrzymaniem, z kontrapunktowo wyrażaną siłą bezruchu ${ }^{123}$. Występ Sylvie Guillem - jak niegdyś Jorgego Donna - na zawsze zapadł w pamięć i emocje widzów.

W tym kontekście wydarzeniem zupełnie wyjątkowym, nawet jak na utrwalony już wysoki poziom lódzkiego festiwalu, stała się cztery lata później, na XXIII ŁSB (2015), prapremiera pożegnalnego programu Guillem. Gwiazda (już jako

122 Kamilla Staszak, Sylvie Guillem - największa wspótczesna primabalerina, „Polityka” (3 marca 2012), https://www.polityka.pl/tygodnikpolityka/ spoleczenstwo/1524501,1,sylvie-guillem---najwieksza-wspolczesna-primabalerina. read ?page $=2 \&$ moduleId $=4686$ (dostęp: 20.09 .2016$)$.

123 Nagrania spektakli są dostępne w internecie, a opisy m.in.: Judith Mackrell, Sylvie Guillem and Russell Maliphant: how we made Push, „The Guardian” (16 July 2014), https://www.theguardian.com/stage/2014/jul/16/sylvie-guillem-russell-maliphant-how-we-made-push (dostęp: 26.07.2016); Sarah Crompton, Sylvie Guillem interview: raising the barre, "The Thelegraph”, https://www.telegraph.co.uk/culture/theatre/dance/8609145/Sylvie-Guillem-interview-raising-the-barre.html (dostęp: 25.08.2016); Igor Rakowski-Kłos, Mademoiselle Non, „Gazeta Wyborcza - Łódź” (20 kwietnia 2011), http://lodz.wyborcza.pl/lodz/1,35135,9473832,Mademoiselle_Non.html (dostęp: 18.08.2016). 
dziewiętnastolatka w 1984 r. obwołana została étoile przez samego Nurejewa) przywiozła spektakl Sylvie Guillem - Life in Progress, pokazany w Łodzi jeszcze przed jego oficjalną premierą $\mathrm{w}$ Londynie. Otwierał przedstawienie nowy utwór pt. technê w choreografii Khana, z muzyką graną na żywo przez kompozytorkę Alies Sluiter (głos, laptop i skrzypce), Prathapa Ramachandrana (perkusja) i Grace Savage (beatbox) ${ }^{124}$, do której tańczyła Guillem. Narracyjnie jej solo było „zdecydowaną a zarazem dowcipną przypowieścią o relacjach natury i technologii” 125 . Drugą część spektaklu stanowiła nowa wersja (z 2015 r.) autorskiego dzieła Williama Forsythe’a (choreografia, scenografia, kostiumy) pt. Duo (1996 r., muzyka Thom Willems), w wykonaniu Brigela Gjoka i Rileya Wattsa. Widoczna synchronizacja ruchowo-muzyczna działań tancerzy (wersja premierowa przeznaczona była dla kobiet) ma tu, jak można przypuszczać, swoje źródło w zjawisku tzw. rytmicznego porwania (ang. rhytmic entrainment), polegającego na „skoordynowanych i rytmicznych ruchach całego ciała wywołanych przetwarzaniem muzyki, przy ograniczeniu świadomego przetwarzania bodźców"126. Inaczej mówiąc: gesty, praca mięśni, oddech, myśli, emocje - wspólnie, choć osobno tańczących ludzi - ulegają synchronizacji, co prowadzi do osiągnięcia niezwykłych stanów świadomości, wzmożenia odczuwania przestrzeni i wzajemnej obecności tańczących. Przykładem i wyrazem takiego zjawiska był ów konceptualny duet. Trzecią propozycją pożegnalnego przedstawienia francuskiej primabaleriny było dzieło Russella Maliphanta pt. Here \& After, w którym dojrzałej artystce partnerowała młoda tancerka z La Scali - Emanuel Montanari. Razem $\mathrm{w}$ tańcu na pulsującej świetlnej szachownicy ${ }^{127}$ (reżyseria światła Hullsa) stworzyły: „Wspaniałe, zmyślne, wyniosłe pas de deux, oparte na zachwycającej, silnej współpracy tancerek i ich doskonałym uzupełnianiu się"128. I wreszcie kwintesencja przedstawienia, stworzone specjalnie dla Guillem (jako fragment

124 Michelle Potter, Sylvie Guillem. „Life in Progress”; strona: Michelle Potter... on dancing, 22 August 2015, https://michellepotter.org/tag/sylvie-guillem (dostęp: 30.08.2016).

125 Dariusz Pawłowski, Łódzkie Spotkania Baletowe: spektakl „Sylvie Guillem - Life In Progress”, „DziennikŁódzki” (19 maja 2015), https: / / dzienniklodzki.pl/lodzkie-spotkania-baletowe-spektakl-sylvie-guillem-life-in-progress/ga/3867897/zd/5375707 (dostęp: 20.09.2016).

126 Piotr Podlipniak, Uniwersalia muzyczne, Wydawnictwo Poznańskiego Towarzystwa Przyjaciół Nauk, Poznań 2007, s. 90; zob. też: Elizabeth Neumann Waterhouse, Riley Watts, Bettina E. Bläsing, Doing Duo - a case study of entrainment in William Forsythe's choreography „Duo”, „Frontiers in Human Neuroscience” (21 October 2014), https:// www.frontiersin.org/articles/10.3389/fnhum.2014.00812/full (dostęp: 20.08.2016).

127 Michelle Potter, Sylvie Guillem...

128 Dariusz Pawłowski, Łódzkie... 
programu 6000 miles away) - Bye w choreografii Matsa Eka, do Arietty z Sonaty fortepianowej c-moll nr 32 op. 111 Beethovena, czyli ostatniej z sonat fortepianowych kompozytora. Artystce, doskonale świadomej swojego posłusznego jej woli ciała, doświadczającej każdym gestem przestrzeni, towarzyszyła projekcja na umieszczonym na scenie ekranie/drzwiach. W finale utworu tancerka dołączała do widocznego na ekranie rosnącego tłumu mężczyzn, kobiet, dzieci i psów i, podążając za nimi, odchodziła w dal ${ }^{129}$. Guillem prowadziła sceniczną opowieść w charakterystycznym dla narracji Eka stylu. Tym tańcem primabalerina żegnała się z publicznością po 39 latach kariery. Upór i konsekwencja w dążeniu do perfekcyjnego wyrażenia własnej wizji artystycznej, bezkompromisowe trwanie przy swoich - estetycznych i światopoglądowych - przekonaniach, przyniosło artystce przydomek Mademoiselle Non. Jej niezwykłą energię, inteligencję, osobowość, charakter tańca i magnetyczny wpływ na publiczność Mats Ek zamknął w określeniu: „She has a blue flame within her”130. A sama nazywa siebie „misjonarką emocji", dbającą przede wszystkim o to, by przekazać uczucia w tańcu najważniejsze - uniesienie, wzruszenie i ekscytację ${ }^{131}$. Takich emocji doświadczyła festiwalowa publiczność podczas każdego spotkania ze sztuką Sylvie Guillem.

Wykonawcza perfekcja tancerek i tancerzy zapraszanych na Łódzkie Spotkania Baletowe zawsze była jedną z wiodących cech Biennale. Spróbujmy syntetycznie podsumować także inne właściwości tego nieprzeciętnego festiwalu.

Pomimo że w ciągu ostatniego półwiecza Spotkaniom wyrosła spora konkurencja ${ }^{132}$, nadal jest to największy i najbardziej prestiżowy festiwal tańca

129 Michelle Potter, Sylvie Guillem...

130 Sarah Crompton, Sylvie Guillem...

131 Kamilla Staszak, Sylvie Guillem...

132 Obecnie organizowanych jest $\mathrm{w}$ Polsce kilkadziesiąt festiwali poświęconych sztuce tańca. Są wśród nich wydarzenia cykliczne i specjalizujące się w wybranych dziedzinach tańca, jak np.: Międzynarodowa Konferencja Tańca Współczesnego i Festiwal Sztuki Tanecznej w Bytomiu, Międzynarodowe Spotkania Teatrów Tańca w Lublinie, Międzynarodowy Festiwal Tańca Współczesnego „Ciało/Umysł”, Festiwal Tańców Dworskich „Cracovia Danza”, Międzynarodowy Festiwal Teatrów Tańca „Dancing Poznań” i Międzynarodowe Warsztaty Tańca Współczesnego; bądź towarzyszące ofercie kulturalnej konkretnych miast, np.: Poznańska Wiosna Baletowa czy Gdański Festiwal Tańca, w tym również te o mniejszej randze, jak np. Łódzka Fiesta Taneczna. Proponuje się także zespół wydarzeń tanecznych prezentowanych w ramach większych imprez kulturalnych, jak np.: Festiwal Malta w Poznaniu, Krakowskie Reminiscencje Teatralne, Międzynarodowe Spotkania Sztuki Akcji „Rozdroża” w Warszawie, czy - na mniejszą skalę - Festiwal Tańca i Muzyki „Noc Żywych Bębnów” w Łodzi. Powstają również wydzielone nurty poświęcone sztuce tańca w ramach większych festiwali artystycznych, np.: Festiwal Improwizacji Tańca połączony z Festiwalem Muzyki Improwizowanej „Ad 
w Polsce, a także jeden z ważniejszych i bardziej liczących się w Europie. Ciągle aktualna jest też, sformułowana przed laty, opinia Tacjanny Wysockiej: „Łódzkie Spotkania Baletowe są wydarzeniem w polskim życiu choreograficznym"133. To tu można zobaczyć, jak rozwijają się nieomal wszystkie kierunki sztuki tańca: od pełnospektaklowych, narracyjnych baletów w stylu akademickim, poprzez różne odmiany modern, post-modern, poszukiwania z kręgu pantomimy, aż po najnowsze propozycje ekspresji przez ruch. Spotkania prezentują i wprowadzają w obieg sztuk performatywnych nowe zjawiska z obszaru tańca, a istniejące - poddają artystycznej konfrontacji i redefinicji. ŁSB są zatem festiwalem podejmującym, w tym obszarze sztuki współczesnej, misję kulturową: kreując wzorce - wpływają na kształt współczesnego tańca w Polsce. Te edukacyjne ambicje Biennale widoczne były szczególnie w organizowaniu warsztatów dla zespołu baletowego Teatru Wielkiego, prowadzonych przez przybywających na Biennale artystów i artystki (np. w czasie XXI ŁSB taki warsztat realizował amerykański choreograf Dennis Callahan). Wypada żałować, że praktyka ta nie została dostatecznie mocno utrwalona.

Organizatorzy festiwalu sporadycznie podejmowali próby tematycznego ukierunkowania jego edycji. Wspomniane XXI Spotkania, poświęcone sztuce choreografii, były autorską koncepcją Stanisława Bromilskiego, przez wiele lat związanego z impresariatem teatralnym, współpracownika znanych europejskich teatrów (m.in. Ballet du XX-e siècle), obecnie doradcy artystycznego i kuratora $Ł S B$. Przez wiele lat rozwoju festiwalu za jego organizację odpowiadała jednak najczęściej dyrekcja TW, później także Impresariat Artystyczny placówki. O charakterze Biennale przesądzała zawsze intencja prezentacji w TW różnorodnej, utrzymanej na wysokim poziomie artystycznym i wewnętrznie zdialogizowanej oferty programowej. Z tej perspektywy ŁSB zbliża się do formuły festiwalu pokazowego europejskiego/światowego tańca, choć - w takim kontekście - nieobecna lub zbyt skromna jest oferta wydarzeń branżowych, przeznaczonych dla polskich twórców tej sztuki. Z pewnością natomiast udział w festiwalu ma znaczenie dla promocji i rozwoju kariery twórców, nie tylko polskich - by przypomnieć Borisa Ejfmana.

Edukacyjny walor Biennale ujawniał się również w organizowaniu imprez towarzyszących. Ich charakter odsłaniał aktualny stan polskiej kultury i sposób myślenia o jej powinnościach. W latach 70. przeprowadzano więc konkursy

Libitum” czy Maat Festival „Peryferie ciała” w ramach Festiwalu Konfrontacje Teatralne w Lublinie. Wreszcie powstają nowe inicjatywy o charakterze projektowym i kuratorskim, jak np.: Przegląd Nowego Tańca w Warszawie czy FRU Festiwal: Polski Festiwal Kontakt Improwizacji w Łodzi.

133 Tacjanna Wysocka, Dzieje baletu ..., s. 529. 
choreograficzne, starając się zapobiec skostnieniu szkolnictwa baletowego. Lata 80. przyniosły najwięcej różnorodnych form tego typu wydarzeń, np.: przeglądy małych form baletowych, wystawy plastyczne o tematyce tanecznej, projekcje filmów baletowych. Na początku lat 90., gdy wyraźnie wzmagał się w kraju ruch warsztatowo-festiwalowy, wznowiono konkurs choreograficzny, organizowano spotkania środowisk baletowych (1991). Wiele ważnych wydarzeń towarzyszących festiwalowi powstało choćby z okazji jubileuszu XX Biennale, w roku 2009. Były wśród nich m.in.: przegląd filmów Taniec i film, performans taneczny Zorki Wolny, wydarzenie interaktywne skupione wokół pracy Katarzyny Kozyry Twarze, wystawy fotografii i malarstwa związanego z tańcem, koncert inauguracyjny przygotowany przez Filharmonię Łódzką im. Artura Rubinsteina. Przykładem bardzo ciekawego pomysłu organizatorów, obliczonego na przyciągnięcie do Teatru nowych widzów, był np. flash mob, zorganizowany w przestrzeni współczesnej łódzkiej agory - na rynku Manufaktury i promujący kolejny XXI ŁSB. 28 kwietnia 2011 roku, na oczach przypadkowych przechodniów, grupa amatorów zaprezentowała choreografię przygotowaną przez Dennisa Callahana.

Nie rezygnowano też z prób powiązania Spotkań z refleksją teoretyczną nad tańcem (np. wspomniane już spotkania naukowe: Teatr i taniec z 1974 r., w którym udział wzięli m.in. Jarzynówna-Sobczak, choreograf Dominique Dupuy i choreolog Gedeon Dienes, sesja Między myśla a gestem. Koncepcje przestrzenno-ruchowe i taneczne $w$ sztuce XX wieku z $1987 \mathrm{r}$. czy konferencja poświęcona Wacławowi Niżyńskiemu w 1989 r.). Jednak takie działania nie przekształciły się $\mathrm{w}$ trwały element $€ S B$, choć byłoby to niezwykle pożądane wobec zasadniczej przemiany, jaka dokonała się w ostatnich dwudziestu latach w sposobach konceptualizacji tańca. Tradycyjne rozpatrywanie tańca w kategoriach ekspresji, formy i reprezentacji staje się dziś bezradne w odniesieniu do nowych strategii artystycznych i ewolucji praktyk tanecznych, zatem zadbanie o otoczenie nowatorskich choreografii - pokazywanych tak często na scenie TW - odpowiednią refleksją krytyczną, stanowiłoby oczekiwany - dla profesjonalistów, ale i sporej grupy entuzjastów Biennale - kierunek rozwoju ŁSB. W trakcie ostatnich kilku festiwali zaczęto natomiast regularnie organizować spotkania z goszczącymi w Łodzi artystami. Rozmowy z twórcami odbywały się po pierwszych spektaklach i przyciągały rzesze zainteresowanych. Prowadzili je krytycy i animatorzy sztuki tańca, dzięki czemu widzowie zyskiwali możliwość wysłuchania specjalistycznej refleksji nad obejrzanym właśnie przedstawieniem, jak również - a to niebagatelna okoliczność dla znacznej części publiczności - „przyjrzenia się z bliska" najbardziej cenionym na świecie artystkom i artystom sztuki tańca oraz podjęcia z nimi rozmowy. Pro domo sua warto wspomnieć, że do budowania myśli krytycznej skupionej wokół ŁSB przyczynili się - w miarę swoich możliwości, ale z nieodmiennym entuzjazmem - studentki/studenci łódzkiej teatrologii. 
Grono współtworzące Studenckie Koło Naukowe Teatrologów, istniejące przy Katedrze Dramatu i Teatru Uniwersytetu Łódzkiego, wydawało w roku 2003 (XVII ŁSB) specjalne pismo poświęcone Biennale, zatytułowane „Pointy” (co miało odnosić się zarówno do tanecznych, jak i literackich znaczeń słowa), w którym młodzi recenzenci/recenzentki opisywali i oceniali każdy spektakl.

Spotkania dbają o rozwijanie kontaktu $\mathrm{z}$ widzami za pośrednictwem nowych mediów i dzisiejszych trybów komunikacji. Teatr Wielki i ŁSB posiadają swoje systematycznie aktualizowane strony internetowe, są także aktywne na portalach społecznościowych, prowadząc tu m.in. sondy dotyczące najbardziej wyczekiwanych przez publiczność artystów. Na szczególne wyróżnienie zasługuje, podjęta w roku 2016, inicjatywa stworzenia Cyfrowego Muzeum Teatru Wielkiego w Łodzi. Dzięki istnieniu tego unikatowego portalu udaje się ocalić pamięć aranżowanych w Teatrze wydarzeń, w tym przypomnieć przebieg i charakter Łódzkich Spotkań Baletowych.

Ponieważ Biennale to bardzo zasłużony festiwal liniowy, rozciągnięty na pólwiecze swego trwania, zdarzały się w jego historii edycje słabsze, nietrafione inicjatywy czy problematyczne zaproszenia. Wynikało to w znacznym stopniu nie tylko z błędów kuratorsko-organizacyjnych, lecz z uzależnienia Biennale - jak każdej instytucji publicznej - od kontekstu społeczno-politycznego, w jakim funkcjonuje. O zmienności tego kontekstu decydowała dramatyczność historii - PRL-u i III Rzeczpospolitej, choć elitarny charakter wydarzenia skutecznie izolował Biennale od rytmu życia miasta i kraju, a rewolucyjne zmiany rzeczywistości zewnętrznej objawiały się w jego losach przede wszystkim w sferze ekonomicznej, wpływającej na artystyczną. Festiwal, który nie wyrósł z tradycji Łodzi i nie reprezentował $w$ chwili swego powstawania rzeczywistych potrzeb kulturowych miasta, budował z nim relacje, sięgając po kategorię prestiżu. Począwszy od czasów PRL-u, ale także w kolejnych dziesiątkach lat, miał stanowić sposób na podniesienie samooceny, zaspokojenie potrzeby wyjątkowości - włodarzy i mieszkańców miasta. Jest zasługą twórców i animatorów $€ S B$, że hierarchię prestiżu z obszarów polityki społecznej udało im się przemieścić w przestrzeń sztuki. Dzięki temu Spotkania stanowią dziś wyjątkowe miejsce wymiany doświadczeń, konwersji praktyk artystycznych, podejmowania i przepływu najnowszych idei sztuki tańca. Łódzkie Spotkania Baletowe - w swoim artystycznym, konceptualnym i towarzyskim wymiarze - umożliwiają prawdziwe SPOTKANIE i wzajemną inspirację artystów oraz wymianę ich myśli i emocji z publicznością, a tym samym rzeczywistą przemianę - przez sztukę. Biennale, nie tworząc w Łodzi atmosfery powszechnego feerycznego święta tańca, dba jednak usilnie o to, by nie stać się sztucznym wydarzeniem, kreowanym przez specjalistów dla grona wybrańców. Dzięki temu dziś stanowi sferę rzeczywistej kulturowej identyfikacji już dla trzech pokoleń łodzian. 


\section{Bibliografia}

[ze względu na liczbę wykorzystanych źródeł podajemy tu tylko podstawowe prace, $\mathrm{z}$ pominięciem tekstów z prasy codziennej, uwzględnionych $\mathrm{w}$ przypisach - M. K., I. J-L.]

Andrzejewska-Psarska Małgorzata, Więcej niż taniec. Rozmowy z Ewą Wycichowska, Polskie Wydawnictwo Muzyczne, Warszawa 2003.

Buchwald Dorota, Wspótczesne festiwale w Polsce. Typologia i geografia, [w:] Między świętem a przesytem. Festiwale teatralne $i$ ich miejsce we wspótczesnym życiu kulturalnym Polski, red. Dariusz Kosiński, Teatr Lalek „Pleciuga”, Szczecin 2016, s. 15-26. Ciało tańczace, „Kultura Współczesna” 2011, nr 3.

Chodkowski Andrzej, Encyklopedia muzyki, Państwowe Wydawnictwo Naukowe, Warszawa 1995.

Domański Adam, Jubileusz sztuki tańca, „Życie Literackie” 1989, nr 21.

Drajewski Stefan, Conrad Drzewiecki. Reformator polskiego baletu, Dom Wydawniczy Rebis, Poznań 2014.

Dyzbardis Stanisław, Łódź tańczy..., „Kalejdoskop” 2005, nr 5.

Graczyk Tomasz, Teatr Wielki w Łodzi 1967-2007, Teatr Wielki w Łodzi, Łódź 2007. Gryglewski Piotr, Wróbel, Robert, Ucińska Agnieszka, Łódzkie budynki 1945-1970, Księży Młyn Dom Wydawniczy, Łódź 2012.

Hajduk Edyta, Zatańcz to jeszcze raz, „Didaskalia. Gazeta Teatralna” 2001, nr 43/44. Janyst Janusz, Sfera Terpsychory, „Tygiel Kultury” 2009, nr 7-9.

Kaszyński Stanisław, Święto baletu. Uwagi i refleksje, „Odgłosy. Tygodnik Społeczno-Kulturalny" 1968, nr 24.

Kaszyński Stanisław, Teatr łódzki w latach 1945-1962, Wydawnictwo Łódzkie, Łódź 1970.

Klimczyk Wojciech, Wizjonerzy ciała. Panorama wspótczesnego teatru tańca, Korporacja HA!ART, Kraków 2010.

Kuligowska-Korzeniewska Anna, Sabina Nowicka. Legenda teatru łódzkiego, „Zeszyty Literackie" 2006, nr 3.

Kwieciński Jerzy, VII Łódzkie Spotkania Baletowe, „Odgłosy. Tygodnik Społeczno-Kulturalny" 1983, nr 22.

Kwieciński Jerzy, X Łódzkie Spotkania Baletowe. Ostatni „krajowcy” i goście z Kuby, „Odgłosy. Tygodnik Społeczno-Kulturalny” 1989, nr 25.

Kwieciński Jerzy, X Łódzkie Spotkania Baletowe. Z zamorskich krajów, „Odgłosy. Tygodnik Społeczno-Kulturalny" 1989, nr 26.

Lenarciński Michał, Oblicza Terpsychory, czyli XI Łódzkie Spotkania Baletowe, „Odgłosy. Tygodnik Społeczno-Kulturalny" 1991, nr 2.

Livio Antoine, Béjart, La Cité, Lausanne, Paris, 1970.

Łódzka scena operowa, red. Krystyna Juszyńska, Akademia Muzyczna im. Grażyny i Kiejstuta Bacewiczów, Łódź 2005. 
Majewska Jadwiga, Jak się tańczy w Ameryce, [w:] Sally Banes, Terpsychora $w$ tenisówkach. Taniec post-modern, przeł. Artur Grabowski, Jadwiga Majewska, Polskie Wydawnictwo Muzyczne SA, Kraków 2013.

Między świętem a przesytem. Festiwale teatralne i ich miejsce we współczesnym życiu kulturalnym Polski, red. Dariusz Kosiński, Teatr Lalek „Pleciuga”, Szczecin 2016.

Nabokina Anastasia, Gtos z oddali, „Teatr” 2013, nr 1.

Pankiewicz Ewa, Powrót tańca, „Odgłosy. Tygodnik Społeczno-Kulturalny” 1981, nr 25.

Podlipniak Piotr, Uniwersalia muzyczne, Wydawnictwo Poznańskiego Towarzystwa Przyjaciół Nauk, Poznań 2007.

Programy teatralne Łódzkich Spotkań Baletowych I-XXII (strona Teatru Wielkiego w Łodzi, http: / / www.operalodz.com/ i archiwum prywatne).

Ratajczakowa Dobrochna, Polski Teatr Tańca - Balet Poznański, [w: ] eadem, $W$ krysztale i $w$ płomieniu. Studia i szkice o dramacie i teatrze, t. 2, wybór i oprac. Barbara Koncewicz, Wydawnictwo Uniwersytetu Wrocławskiego, Wrocław 2006.

Smużniak Karol, Teatr milczenia i dramat przemilczeń, Wyższa Szkoła Pedagogiczna im. Tadeusza Kotarbińskiego, Zielona Góra 1996.

Smużniak Karol, Teatr pantomimy Henryka Tomaszewskiego: prolegomena do teorii teatru pantomimy, Oficyna Wydawnicza Uniwersytetu Zielonogórskiego, Zielona Góra 2004.

Stanisławska Aleksandra, Feliks Parnell - narodziny baletu tódzkiego, [w: ] Łódzka scena operowa, red. Krystyna Juszyńska, Akademia Muzyczna im. Grażyny i Kiejstuta Bacewiczów, Łódź 2005, s. 245-254.

Sto lat stałej sceny polskiej w Łodzi 1888-1988, red. Anna Kuligowska, Towarzystwo Przyjaciół Łodzi, Łódź 1993.

Szymajda Joanna, Tendencje estetyczne we wspótczesnym tańcu francuskim po 1990 roku, Łódź 2005.

Teatr Wielki w Łodzi 1967-2007, red. Tomasz Graczyk, Łódź 2006.

Teatr Wielki w Łodzi, red. Stanisław Dyzbardis, Teatr Wielki w Łodzi, Łódź 1966.

Turska Irena, Almanach baletu polskiego, 1945-1974, Polskie Wydawnictwo Muzyczne, Kraków 1983.

Wojciechowska Teresa, III Łódzkie Spotkania Baletowe, „Odgłosy. Tygodnik Społeczno-Kulturalny" 1972, nr 24.

Wysocka Tacjanna, Dzieje baletu, Państwowy Instytut Wydawniczy, Warszawa 1970.

XL. Polski Teatr Tańca wczoraj i dziś, audio-video performance w 10 odcinkach: Krzesany i inne tańce, red. Jagoda Ignaczak, PTT Poznań 2012/2013. 


\section{Netografia}

[podstawowe źródła]

(dostęp: 15.10.2016)

http://www.encyklopediateatru.pl/

http://www.operalodz.com/

http://www.taniecpolska.pl/

https://operabaltycka.pl/

www.maestro.net.pl 